\title{
URINARY ALPHA-KETOLIC STEROID METABOLITES OF COR- TICAL HORMONES ADMINISTERED TO SUBJECTS WITH ADRENAL CORTICAL INSUFFICIENCY ${ }^{1}$
}

\author{
By E. M. RICHARDSON, J. C. TOUCHSTONE, AND F. C. DOHAN WITH THE TECHNICAL \\ ASSISTANCE OF HELEN BULASCHENKO, IRMGARD LANDOLT, AND \\ WALTER APPLIN \\ (From the Endocrine Section of the William Pepper Laboratory of Clinical Medicine, Uni- \\ versity of Pennsylvania, and the Department of Medicine, School of Medicine, \\ University of Pennsylvania, Philadelphia, Pa.)
}

(Submitted for publication June 21, 1954 ; accepted October 27, 1954)

The analysis of urinary excretory products following the administration of known compounds is one of the classical methods for the study of their metabolism. The developments in paper chromatographic (1) and micro-analytic (2) technics and the use of glucuronidase hydrolysis (3) have considerably decreased the difficulties of investigating steroid metabolism by this method. Using these newer technics, we have studied the urinary excretion pattern of the major alpha-ketolic steroids after the administration of the six "active" adrenal cortical steroids to individuals with severe adrenal cortical insufficiency. We have found, as has been demonstrated for other steroids (4), that the major alpha-ketolic metabolites result from the reduction in ring $A$ of the steroid nucleus to the 3-alpha-hydroxy pregnane derivatives (the socalled "tetrahydro" form) and that the hydroxyl and ketone groups on carbon atom 11 are interconvertible for corticosterone and 11-dehydrocorticosterone as well as for hydrocortisone and cortisone.

\section{METHODS}

\section{Terminology}

Since steroid terminology is varied and the proper chemical names consume considerable space, the terms and abbreviations more commonly used in physiological research will be employed in this paper. Definitions and abbreviations are listed below.

Alpha-ketolic steroids: Pregnane derivatives having 20-keto and 21-hydroxy substituents (i.e., alpha-ketol group).

1 This investigation was supported in part by research grant H-922 from the National Heart Institute, of the National Institutes of Health, Public Health Service; and by grants from the American Heart Association, the Helon Augusta Parkhill Memorial Fund, Eli Lilly and Company and the Ciba Pharmaceutical Products, Inc.
Alpha-ketolic cortical hormones: The six alpha-ketolic steroids with physiological activity, also exhibiting an alpha-beta unsaturated ketone in ring $A$ ( $\Delta^{4}$-pregnene type). These are:

F; Compound F (Kendall); hydrocortisone ; $\Delta^{4}$-pregnene-11- $\beta, 17 \alpha, 21-$ triol-3, 20-dione.

$\mathrm{E}$; Compound $\mathrm{E}$ (Kendall) ; cortisone ; $\Delta^{4}$-pregnene$17 \alpha, 21$-diol-3, 11, 20-trione.

$\mathrm{S}$; Compound S (Reichstein) ; 11-desoxy-17-hydroxycorticosterone; $\Delta^{4}$-pregnene-17 $\alpha, 21$-diol-3, 20- dione.

B ; Compound B (Kendall) ; corticosterone; $\Delta^{4}$-pregnene-11- $\beta, 21-$ diol-3, 20-dione.

A ; Compound A (Kendall) ; 11-dehydrocorticosterone; $\Delta^{4}$-pregnene-21-ol-3, 11, 20-trione.

DOC; 11-desoxycorticosterone ; $\Delta^{4}$-pregnene-21-ol-3, 20dione.

These are listed in order of decreasing polarity. The acetate is indicated by the abbreviation ac.

Alpha-ketolic steroid metabolites ( $A K S M)$ : Steroids with the alpha-ketolic side chain found in the urine. These are detectable by reaction of the alpha-ketol side chain with alkaline blue tetrazolium to produce a blue color. The unmodified abbreviation $\mathrm{H}_{4}$ indicates reduction in ring $A$ to form the $3 \alpha$ normal (i.e., pregnane) reduction product. In addition to the alpha-ketolic cortical hormones, the major metabolites are:

$\mathrm{H}_{\mathbf{1}} \mathrm{F}$; tetrahydro-hydrocortisone; pregnane-3 $\alpha, 11 \beta$, $17 \alpha, 21$-tetrol-20-one.

$\mathrm{H}_{4} \mathrm{E}$; tetrahydro-cortisone; pregnane-3 $\alpha, 17 \alpha, 21$-triol11, 20-dione.

$\mathrm{H}_{4} \mathrm{~S}$; tetrahydro-11-desoxy-17-hydroxycorticosterone ; pregnane-3 $\alpha, 17 \alpha, 21$-triol-20-one.

$\mathrm{H}_{4} \mathrm{~B}$; tetrahydro-corticosterone ; pregnane-3 $\alpha, 11 \beta, 21$ triol-20-one.

$\mathrm{H}_{4} \mathrm{~A}$; tetrahydro-dehydrocorticosterone ; pregnane-3 $\alpha$, 21-diol-11, 20-dione.

$\mathrm{H}_{4} \mathrm{DOC}$; tetrahydro-11-desoxycorticosterone; pregnane-3 $\alpha, 21$-diol-20-one.

Polarity: In the chromatograms, the most polar steroids (i.e., those with the most hydroxyl and keto substituents) appear in the slowest moving fraction, $X$, and the least polar in the fastest moving fraction, $Z$. (See III, B Paper chromatographic and micro-analytic technics.) 
TABLE I

Urinary alpha-ketolic steroid metabolites: Identification studies *

\begin{tabular}{|c|c|c|c|c|c|c|c|c|c|c|c|}
\hline \multirow[b]{2}{*}{$\begin{array}{l}\text { Oral dose } \\
\text { per day }\end{array}$} & \multirow[b]{2}{*}{$\begin{array}{l}\text { Frac- } \\
\text { tion } \\
\text { and } \\
\text { peak } \\
\text { no. }\end{array}$} & \multirow[b]{2}{*}{$\frac{\text { Standard steroid }}{\text { Compound isolated }}$} & \multicolumn{2}{|c|}{ Rooct } & \multirow[b]{2}{*}{$\begin{array}{c}\text { U.V. } \\
\text { absorb. } \\
245 \mathrm{m \mu} \text {. }\end{array}$} & \multirow[b]{2}{*}{$\begin{array}{l}\text { Porter- } \\
\text { Silber }\end{array}$} & & & & & \multirow[b]{2}{*}{ Other } \\
\hline & & & $\begin{array}{c}\text { Toluene/ } \\
\text { P.G. } \\
\text { (free) }\end{array}$ & $\begin{array}{l}\text { Me. cyclo- } \\
\text { hexane/ } \\
\text { P.G. } \\
\text { (acetate) }\end{array}$ & & & \multicolumn{4}{|c|}{$\begin{array}{c}\text { Maxima of spectra } \\
\text { in } \mathrm{H}_{2} \mathrm{SO}_{4}\end{array}$} & \\
\hline \multirow{6}{*}{$\begin{array}{l}F_{A O} \\
400 \text { mg. } \\
\text { Exp. No. } 1\end{array}$} & $X_{1}$ & $\mathrm{H}_{4} \mathrm{~F}$ & $\begin{array}{l}.0060 \\
.0054\end{array}$ & $\begin{array}{l}.19 \\
.22\end{array}$ & $\begin{array}{l}\mathbf{0} \\
\mathbf{0}\end{array}$ & + & $\begin{array}{l}260 \\
256\end{array}$ & $\begin{array}{l}330 \\
320\end{array}$ & $\begin{array}{l}415 \\
410\end{array}$ & $\begin{array}{l}515 \\
510\end{array}$ & \\
\hline & $\mathrm{X}_{2}$ & $\mathrm{H}_{4} \mathrm{E}$ & $\begin{array}{l}.0085 \\
.0076\end{array}$ & $\begin{array}{l}.40 \\
.40\end{array}$ & $\begin{array}{l}\mathbf{0} \\
\mathbf{0}\end{array}$ & $\dot{t}$ & $\begin{array}{l}272 \\
270\end{array}$ & $\begin{array}{l}330 \\
325\end{array}$ & $\begin{array}{l}410 \\
410\end{array}$ & 二 & \\
\hline & $X_{2 a}$ & Unknown & $.012 \ddagger$ & 一 & 0 & - & - & - & - & - & \\
\hline & $\mathbf{X}_{3}$ & $\mathbf{F}$ & $\begin{array}{l}.017 \\
.017\end{array}$ & - & $\stackrel{+}{+}$ & $\stackrel{+}{+}$ & $\begin{array}{l}240 \\
240\end{array}$ & $\begin{array}{l}280 \\
276\end{array}$ & $\begin{array}{l}390 \\
385\end{array}$ & $\begin{array}{l}475 \\
480\end{array}$ & $\begin{array}{l}\text { Fluorescence + } \\
\text { Fluorescence }+\end{array}$ \\
\hline & $\mathbf{X}_{\mathbf{8 a}}$ & Unknown & $.027 \ddagger$ & - & - & - & - & - & 一 & - & \\
\hline & $X_{4}$ & $E$ & $\begin{array}{l}.041 \\
.036\end{array}$ & $\begin{array}{l}.013 \\
.013\end{array}$ & + & + & $\begin{array}{l}280 \\
280\end{array}$ & $\begin{array}{l}340 \\
330\end{array}$ & $\begin{array}{l}415 \\
420\end{array}$ & - & \\
\hline \multirow{6}{*}{$\begin{array}{l}E_{A C} \\
200 \text { mg. } \\
\text { Exp. No. } 3\end{array}$} & $\mathrm{X}_{1}$ & $\mathrm{H}_{4} \mathrm{~F}$ & $\begin{array}{l}.0060 \\
.0054\end{array}$ & $\begin{array}{l}.19 \\
.25\end{array}$ & $\begin{array}{l}0 \\
0\end{array}$ & + & $\begin{array}{l}260 \\
260\end{array}$ & $\begin{array}{l}330 \\
330\end{array}$ & $\begin{array}{l}415 \\
410\end{array}$ & $\begin{array}{l}510 \\
510\end{array}$ & $\begin{array}{l}\text { Infrared } \\
\text { Infrared }\end{array}$ \\
\hline & $\mathrm{X}_{2}$ & $\mathrm{H}_{4} \mathrm{E}$ & $\begin{array}{l}.0085 \\
.0088\end{array}$ & $\begin{array}{l}.40 \\
.40\end{array}$ & $\begin{array}{l}\mathbf{0} \\
\mathbf{0}\end{array}$ & + & $\begin{array}{l}270 \\
276\end{array}$ & $\begin{array}{l}335 \\
335\end{array}$ & $\begin{array}{l}410 \\
410\end{array}$ & 二 & $\begin{array}{l}\text { Infrared } \\
\text { Infrared }\end{array}$ \\
\hline & $\mathbf{X}_{2 a}$ & Unknown & $.012 \ddagger$ & 一 & 0 & - & - & - & - & - & \\
\hline & $\mathbf{X}_{3}$ & $\mathbf{F}$ & $\begin{array}{l}.017 \\
.020\end{array}$ & - & $\dot{t}$ & + & $\begin{array}{l}240 \\
240\end{array}$ & $\begin{array}{l}280 \\
280\end{array}$ & $\begin{array}{l}390 \\
385\end{array}$ & $\begin{array}{l}475 \\
475\end{array}$ & $\begin{array}{l}\text { Fluorescence }+ \\
\text { Fluorescence }+\end{array}$ \\
\hline & $X_{4}$ & $\mathrm{E}$ & $\begin{array}{l}.0418 \\
.041\end{array}$ & - & + & + & $\begin{array}{l}280 \\
276\end{array}$ & $\begin{array}{l}340 \\
340\end{array}$ & $\begin{array}{l}410 \\
415\end{array}$ & - & $\begin{array}{l}\text { Infrared } \\
\text { Infrared }\end{array}$ \\
\hline & $Y_{1}$ & $\mathrm{H}_{2} \mathrm{E}$ & $\begin{array}{l}.069 \| \\
.069\end{array}$ & $\begin{array}{l}.036 \\
.037\end{array}$ & $\begin{array}{l}\mathbf{0} \\
\mathbf{0}\end{array}$ & + & - & - & 二 & - & \\
\hline $\begin{array}{l}S_{A C} \\
100 \text { mg. } \\
\text { Exp. No. } 11\end{array}$ & $\mathrm{X}_{1}$ & $\mathrm{H}_{4} \mathrm{~S}$ & $\begin{array}{l}.037 \\
.045\end{array}$ & $\begin{array}{l}3.8 \\
4.3\end{array}$ & $\begin{array}{l}\mathbf{0} \\
\mathbf{0}\end{array}$ & + & $\begin{array}{l}315 \\
315\end{array}$ & $\begin{array}{l}410 \\
410\end{array}$ & - & - & $\begin{array}{l}\text { Infrared } \\
\text { Infrared }\end{array}$ \\
\hline
\end{tabular}

* Comment concerning identification: Isolated compounds showing similar infrared spectra or similar spectra in sulfuric acid to the standard steroid as well as similar running rates and other listed characteristics are considered to be positively identified. For absolute identification of the "tetrahydro" and "dihydro" compounds, infrared spectrometry is essential since the sulfuric acid absorption spectra of the C-3 and C-5 stereoisomers are similar.

The identity of the compounds not subjected to these spectrometric studies is less certain but it is believed that peak $Y_{1}$ (exp. No. 3) found after administration of $200 \mathrm{mg}$. of $E_{n o}$ is probably $H_{2} E$ since: 1) the $R_{D o c}$ both as the free and acetylated form was similar to $\mathrm{H}_{2} \mathrm{E}$ in the toluene-propylene glycol system and as the acetylated form in the methylcyclohexane-propylene glycol system, and 2) the compound did not absorb ultraviolet light at $245 \mathrm{~m} \mu$ but did give a quantitatively positive Porter-Silber reaction. In addition $\mathrm{H}_{2} \mathrm{E}$ has been identified by Schneider (27) in extracts of normal male urine. In the less extensively studied experiments (below the double line) the evidence concerning identity is largely inferential. See discussion concerning possibility of peaks $Y_{2}$ and $Z_{2}$ in experiments No. 12 and No. 5 being the allo isomers of $\mathrm{H}_{4} B$ and $\mathrm{H}_{4} \mathrm{~A}$.

$\dagger$ The data for the standard steroid are written above those for the isolated steroid. (See Methods for significance

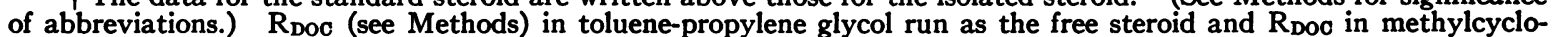
hexane-propylene glycol run as the acetate.

$\ddagger$ Note similarity of $R_{D O c}$ of peaks $X_{2 a}$ in experiments No. 1, No. 3, and No. 10 ; peaks $X_{3 a}$ in experiments No. 1 and No. 9 ; peaks $Y_{2}$ in experiments No. 12 , No. 5 , and No. 13 ; and peaks $Z_{2}$ in experiments No. 12 and No. 5 .

\& ROC run as acetates in toluene-propylene glycol system was 0.31 for unknown and for standard of $E_{20}$

$R_{\text {DOc }}$ run as acetates in toluene-propylene glycol system was 0.47 for unknown and 0.51 for standard $\mathrm{H}_{2} E_{20}$

If $R_{D O C}$ run as free compound in methylcyclohexane-propylene glycol system was 0.034 (unknown $Z_{2}$ after administration of $B$, exp. No. 12).

** $R_{D O C}$ run as free compound in methylcyclohexane-propylene glycol system was 0.07 for unknown and for standard compound A.

t† $R_{\text {DOC }}$ run as free compound in methylcyclohexane-propylene glycol system was 0.036 (unknown $Z_{2}$ after administration of $A_{2 c}$, exp. No. 5, compare with note T above).

¥ Free compound in methylcyclohexane-propylene glycol system. 
TABLE I-Continued

\begin{tabular}{|c|c|c|c|c|c|c|c|c|c|c|c|}
\hline \multirow[b]{2}{*}{$\begin{array}{c}\text { Oral dose } \\
\text { per day }\end{array}$} & \multirow[b]{2}{*}{$\begin{array}{c}\text { Frac- } \\
\text { tion } \\
\text { and } \\
\text { peak } \\
\text { no. } \\
\end{array}$} & \multirow[b]{2}{*}{$\frac{\text { Standard steroid }}{\text { Compound isolated }}$} & \multicolumn{2}{|c|}{ Rooct } & \multirow[b]{2}{*}{$\begin{array}{l}\text { U.V. } \\
\text { absorb. } \\
245 \mathrm{~mm} \text {. }\end{array}$} & \multirow[b]{2}{*}{$\begin{array}{l}\text { Porter- } \\
\text { Silber }\end{array}$} & \multirow{2}{*}{\multicolumn{4}{|c|}{$\begin{array}{c}\text { Maxima of spectra } \\
\text { in } \mathrm{H}_{3} \mathrm{SO}_{4}\end{array}$}} & \multirow[b]{2}{*}{ Other } \\
\hline & & & $\begin{array}{l}\text { Toluene/ } \\
\text { P.G. } \\
\text { (free) }\end{array}$ & $\begin{array}{l}\text { Me. cyclo- } \\
\text { hexane/ } \\
\text { P.G. } \\
\text { (acetate) }\end{array}$ & & & & & & & \\
\hline \multirow{6}{*}{$\begin{array}{l}\text { BALO } \\
90 \mathrm{mg} \text {. } \\
\text { Exp. No. } 12\end{array}$} & $Y_{1}$ & $\mathrm{H}_{4} \mathrm{~B}$ & $\begin{array}{l}.066 \\
.069\end{array}$ & $\begin{array}{l}3.2 \\
3.2\end{array}$ & $\begin{array}{l}0 \\
0\end{array}$ & $\begin{array}{l}\mathbf{0} \\
\mathbf{0}\end{array}$ & $=$ & $=$ & 二 & 二 & $\begin{array}{l}\text { Infrared } \\
\text { Infrared }\end{array}$ \\
\hline & $\mathbf{Y}_{2}$ & Allo- $\mathrm{H}_{4} \mathrm{~B}$ & .11 & $\begin{array}{l}2.9 \\
3.0\end{array}$ & $\begin{array}{l}\mathbf{0} \\
\mathbf{0}\end{array}$ & $\begin{array}{l}\mathbf{0} \\
\mathbf{0}\end{array}$ & $\begin{array}{l}320 \\
310\end{array}$ & $\begin{array}{l}410 \\
420\end{array}$ & - & - & \\
\hline & $Y_{3}$ & $\mathrm{H}_{4} \mathrm{~A}$ & .14 & $\begin{array}{l}5.6 \\
5.9\end{array}$ & $\begin{array}{l}\mathbf{0} \\
\mathbf{0}\end{array}$ & $\begin{array}{l}\mathbf{0} \\
\mathbf{0}\end{array}$ & $\begin{array}{l}290 \\
292\end{array}$ & $\begin{array}{l}355 \\
355\end{array}$ & $\begin{array}{l}415 \\
410\end{array}$ & $=$ & \\
\hline & $Z_{1}$ & B & $\begin{array}{l}.20 \\
.20\end{array}$ & $\begin{array}{l}.15 \\
.17\end{array}$ & $\stackrel{+}{+}$ & $\begin{array}{l}0 \\
0\end{array}$ & $=$ & $=$ & 二 & 二 & $\begin{array}{l}\text { Fluorescence + } \\
\text { Fluorescence }+\end{array}$ \\
\hline & $Z_{2}$ & Unknown & $.18 \ddagger$ & 4.4 ฯ & 0 & 0 & - & - & - & - & \\
\hline & $\mathrm{Z}_{\mathbf{3}}$ & A & $\begin{array}{l}.50 \\
.50\end{array}$ & $\begin{array}{l}.52^{* *} \\
.42\end{array}$ & $\stackrel{+}{+}$ & $\overline{-}$ & $\begin{array}{l}280 \\
284\end{array}$ & $\begin{array}{l}355 \\
355\end{array}$ & $\begin{array}{l}415 \\
410\end{array}$ & 二 & \\
\hline \multirow{6}{*}{$\begin{array}{l}A_{A C} \\
200 \text { mg. } \\
\text { Exp. No. } 5\end{array}$} & $Y_{1}$ & $\mathrm{H}_{4} \mathrm{~B}$ & $\begin{array}{l}.066 \\
.069\end{array}$ & $\begin{array}{l}3.2 \\
3.6\end{array}$ & $\begin{array}{l}\mathbf{0} \\
\mathbf{0}\end{array}$ & $\begin{array}{l}\mathbf{0} \\
\mathbf{0}\end{array}$ & $\begin{array}{l}310 \\
310\end{array}$ & $\begin{array}{l}415 \\
420\end{array}$ & - & 二 & \\
\hline & $\mathbf{Y}_{2}$ & Allo-H،B & $\begin{array}{l}.11 \\
.10 \ddagger\end{array}$ & $\begin{array}{l}2.9 \\
3.0\end{array}$ & $\begin{array}{l}\mathbf{0} \\
\mathbf{0}\end{array}$ & $\begin{array}{l}0 \\
0\end{array}$ & $=$ & $=$ & 二 & $=$ & \\
\hline & $Y_{2}$ & $\mathrm{H}_{4} \mathrm{~A}$ & $\begin{array}{l}.14 \\
.14\end{array}$ & $\begin{array}{l}5.6 \\
5.5\end{array}$ & $\begin{array}{l}\mathbf{0} \\
\mathbf{0}\end{array}$ & $\begin{array}{l}0 \\
0\end{array}$ & $\begin{array}{l}290 \\
292\end{array}$ & $\begin{array}{l}350 \\
355\end{array}$ & $\begin{array}{l}415 \\
410\end{array}$ & 二 & \\
\hline & $Z_{1}$ & B & $\begin{array}{l}.20 \\
.21\end{array}$ & $\begin{array}{l}.15 \\
.17\end{array}$ & + & $\begin{array}{l}\mathbf{0} \\
\mathbf{0}\end{array}$ & $\begin{array}{l}284 \\
285\end{array}$ & $\begin{array}{l}320 \\
330\end{array}$ & $\begin{array}{l}375 \\
373\end{array}$ & $\begin{array}{l}450 \\
455\end{array}$ & $\begin{array}{l}\text { Fluorescence }+ \\
\text { Fluorescence }+\end{array}$ \\
\hline & $Z_{2}$ & Unknown & $.18 \ddagger$ & $4.4+\dagger$ & 0 & 0 & 292 & 355 & 410 & - & \\
\hline & $Z_{3}$ & A & $\begin{array}{l}.50 \\
.55\end{array}$ & $\begin{array}{l}.52 \\
.47\end{array}$ & + & $\begin{array}{l}\mathbf{0} \\
\mathbf{0}\end{array}$ & $\begin{array}{l}284 \\
284\end{array}$ & $\begin{array}{l}355 \\
355\end{array}$ & $\begin{array}{l}410 \\
410\end{array}$ & 二 & $\begin{array}{l}\text { Infrared } \\
\text { Infrared }\end{array}$ \\
\hline \multirow{3}{*}{$\begin{array}{l}A_{A C} \\
100 \text { mg. } \\
\text { Exp. No. } 13\end{array}$} & $Y_{1}$ & $\mathrm{H}_{4} \mathrm{~B}$ & $\begin{array}{l}.066 \\
.067\end{array}$ & $\begin{array}{l}3.2 \\
3.6\end{array}$ & $\begin{array}{l}0 \\
0\end{array}$ & $\overline{-}$ & $\begin{array}{l}315 \\
315\end{array}$ & $\begin{array}{l}410 \\
410\end{array}$ & 二 & 二 & \\
\hline & $\mathbf{Y}_{2}$ & Allo- $\mathrm{H}_{4} \mathrm{~B}$ & $\begin{array}{l}.11 \\
.12 \ddagger\end{array}$ & $\begin{array}{l}2.9 \\
3.0\end{array}$ & $\begin{array}{l}0 \\
0\end{array}$ & $\overline{-}$ & $=$ & $=$ & 二 & 二 & \\
\hline & $Y_{8}$ & $\mathrm{H}_{4} \mathrm{~A}$ & $\begin{array}{l}.14 \\
.13\end{array}$ & 二 & $\begin{array}{l}\mathbf{0} \\
\mathbf{0}\end{array}$ & $\overline{-}$ & $\begin{array}{l}290 \\
292\end{array}$ & $\begin{array}{l}355 \\
355\end{array}$ & $\begin{array}{l}415 \\
410\end{array}$ & 二 & $\begin{array}{l}\text { Infrared } \\
\text { Infrared }\end{array}$ \\
\hline \multirow{2}{*}{$\begin{array}{l}\text { DOC } \\
200 \text { mg. } \\
\text { Exp. No. } 6\end{array}$} & $Z_{1}$ & $\mathrm{H}_{4} \mathrm{DOC}$ & $\begin{array}{l}.31 \\
.33\end{array}$ & $\begin{array}{l}17.0 \\
18.0\end{array}$ & $\begin{array}{l}\mathbf{0} \\
\mathbf{0}\end{array}$ & $\begin{array}{l}\mathbf{0} \\
\mathbf{0}\end{array}$ & $\overline{300}$ & $\overline{360}$ & $\overline{430}$ & 二 & $\begin{array}{l}\text { Infrared } \\
\text { Infrared }\end{array}$ \\
\hline & $Z_{2}$ & DOC & $\begin{array}{l}1.0 \\
1.0\end{array}$ & $\begin{array}{l}3.3 \\
3.0\end{array}$ & + & $\begin{array}{l}\mathbf{0} \\
\mathbf{0}\end{array}$ & $\begin{array}{l}285 \\
288\end{array}$ & $\begin{array}{l}370 \\
370\end{array}$ & $\begin{array}{l}440 \\
440\end{array}$ & 二 & $\begin{array}{l}\text { Anthrone + } \\
\text { Anthrone }+\end{array}$ \\
\hline \multicolumn{12}{|c|}{ Less extensively studied experiments } \\
\hline \multirow{5}{*}{$\begin{array}{l}F_{A 0} \\
100 \text { mg. } \\
\text { Exp. No. } 9\end{array}$} & $\mathbf{X}_{\mathbf{1}}$ & $\mathrm{H}_{4} \mathbf{F}$ & $\begin{array}{l}.0060 \\
.0062\end{array}$ & $\overline{-}$ & $\begin{array}{l}\mathbf{0} \\
\mathbf{0}\end{array}$ & & & & & & \\
\hline & $\mathbf{X}_{2}$ & $\mathrm{H}_{4} \mathrm{E}$ & $\begin{array}{l}.0085 \\
.0093\end{array}$ & 二 & $\begin{array}{l}\mathbf{0} \\
\mathbf{0}\end{array}$ & & & & & & \\
\hline & $\mathbf{x}_{\mathbf{z}}$ & F & $\begin{array}{l}.017 \\
.017\end{array}$ & - & + & & & & & & $\begin{array}{l}\text { Fluorescence }+ \\
\text { Fluorescence }+\end{array}$ \\
\hline & $\mathbf{X}_{\mathbf{2 n}}$ & Unknown & $.029 \ddagger$ & - & $\mathbf{0}$ & & & & & & \\
\hline & $\mathbf{X}_{4}$ & $\mathbf{E}$ & $\begin{array}{l}.041 \\
.041\end{array}$ & 二 & + & & & & & & \\
\hline
\end{tabular}


TABLE I-Continued

\begin{tabular}{|c|c|c|c|c|c|c|c|c|}
\hline \multirow[b]{2}{*}{$\begin{array}{c}\text { Oral dose } \\
\text { per day }\end{array}$} & \multirow[b]{2}{*}{$\begin{array}{c}\text { Frac- } \\
\text { tion } \\
\text { and } \\
\text { peak } \\
\text { no. } \\
\end{array}$} & \multirow[b]{2}{*}{$\frac{\text { Standard steroid }}{\text { Compound isolated }} \dagger$} & \multicolumn{2}{|c|}{ Rooct } & \multirow[b]{2}{*}{$\begin{array}{c}\text { U.V. } \\
\text { absorb. } \\
245 \mathrm{~m} \mu .\end{array}$} & \multirow[b]{2}{*}{$\begin{array}{l}\text { Porter- } \\
\text { Silber }\end{array}$} & \multirow[b]{2}{*}{$\begin{array}{c}\text { Maxima of spectra } \\
\text { in } \mathrm{H}_{2} \mathrm{SO}_{4}\end{array}$} & \multirow[b]{2}{*}{ Other } \\
\hline & & & $\begin{array}{l}\text { Toluene/ } \\
\text { P.G. } \\
\text { (free) }\end{array}$ & $\begin{array}{l}\text { Me. cyclo- } \\
\text { hexane/ } \\
\text { P.G. } \\
\text { (acetate) }\end{array}$ & & & & \\
\hline \multirow{5}{*}{$\begin{array}{l}E_{A C} \\
100 \text { mg. } \\
\text { Exp. No. } 10\end{array}$} & $\mathrm{X}_{1}$ & $\mathrm{H}_{4} \mathrm{~F}$ & $\begin{array}{l}.0060 \\
.0056\end{array}$ & 二 & $\begin{array}{l}0 \\
0\end{array}$ & & & \multirow{5}{*}{$\begin{array}{l}\text { Fluorescence }+ \\
\text { Fluorescence }+\end{array}$} \\
\hline & $\mathrm{X}_{2}$ & $\mathrm{H}_{4} \mathrm{E}$ & $\begin{array}{l}.0085 \\
.0085\end{array}$ & z & $\begin{array}{l}0 \\
0\end{array}$ & & & \\
\hline & $\mathrm{X}_{2 \mathrm{~s}}$ & Unknown & $.013 \ddagger$ & 一 & - & & & \\
\hline & $\mathrm{X}_{3}$ & F & $\begin{array}{l}.017 \\
.017\end{array}$ & 二 & + & & & \\
\hline & $X_{4}$ & $\mathrm{E}$ & $\begin{array}{l}.041 \\
.041\end{array}$ & $\begin{array}{l}.013 \\
.012\end{array}$ & $\stackrel{+}{+}$ & & & \\
\hline \multirow{2}{*}{$\begin{array}{l}\mathrm{DOC}_{\mathrm{AC}} \\
100 \mathrm{mg} . \\
\text { Exp. No. } 14\end{array}$} & $Z_{1}$ & $\mathrm{H}_{4} \mathrm{DOC}$ & - & - & $\begin{array}{l}\mathbf{0} \\
\mathbf{0}\end{array}$ & & & \\
\hline & $Z_{2}$ & DOC & 二 & $\begin{array}{l}1.0 \pm \ddagger t \\
.98\end{array}$ & + & & & $\begin{array}{l}\text { Anthrone + } \\
\text { Anthrone + }\end{array}$ \\
\hline
\end{tabular}

$R_{\text {Doo: }}$ Mobility of compound compared to 11-desoxycorticosterone. (See Identification Technics.)

"Group reaction": Reactions given by a number of steroids having common chemical properties which depend primarily upon substituent groups. These include the reaction with blue tetrazolium of the alpha-ketolic side chain, reduction of phosphomolybdic acid by material extracted after acid hydrolysis (Ac. R-L), and that extractable after hydrolysis with glucuronidase and acid (G'ase R-L) (so-called reducing lipids, corticoids, lipidsoluble material with reducing properties due to the alphaketolic side chain and/or unsaturated ketone in ring A), and the total neutral 17-ketosteroids (17-KS), i.e., those substances giving the Zimmerman reaction in neutral urinary extracts not subjected to separation with Girard's reagent. The reaction is primarily due to the presence of a keto group at carbon atom 17 , but keto groups at other positions may react to some extent.

Identification: When used without modification this term indicates that the isolated alpha-ketolic steroid has been subjected to spectrometry in sulfuric acid or infrared spectrometry, or both, as well as the following tests (with a few exceptions):

1. Reaction with alkaline blue tetrazolium.

2. $R_{\text {Doo }}$ in two or more solvent systems as free and acetylated forms.

3. Ultraviolet light absorption at $245 \mathrm{~m} \mu$.

4. Phenylhydrazine reaction.

5. And other appropriate tests as indicated in Table I and under chemical methods.

It is emphasized that so-called identification based only on position on the chromatogram and one or two reactions is not considered adequate.

\section{Experimental Procedures}

\section{A. Subjects}

Case No. 1. Severe secondary adrenal cortical insufficiency. Subject AL., a 30-year-old Negro housewife, was studied over the period November 25, 1951 to February 18,1953 . She exhibited classical evidence of severe insufficiency of the anterior pituitary for one and one-half years prior to starting the study. This was presumably due to a non-functioning tumor as indicated by enlargement of sella turcica by $x$-ray. Visual field studies showed no evidence of pressure on the optic nerves. Throughout the period of special study, she was maintained in fairly good condition by androgens and estrogens which were stopped for 48 hours or more prior to administration of the compound to be studied.

Case No. 2. An adrenalectomized, orchidectomized man. Subject SCH. had his testes removed for prostatic carcinoma three years prior to his bilateral adrenalectomy at the age of 65 years. The studies were made one month after adrenalectomy when he was admitted to the hospital on December 9, 1952, with signs of insufficiency of adrenal cortical replacement therapy.

Case No. 3. Severe primary adrenal cortical insufficiency. Subject JO., a 55-year-old male scientist, had suffered from Addison's disease for five years prior to the studies which were made from the period November 19, 1951 to February 18, 1952. During this period, no special therapy was given or needed since he had a subcutaneous pellet of 11-desoxycorticosterone acetate implanted on July 21, 1951. Shortly after completion of the studies, he showed mild signs of possible adrenal insufficiency and additional therapy was given. Chromatograms are not illustrated but showed patterns after F, E, $\mathrm{S}$, and DOC similar to those shown in Figures 1 and 2 . 


\section{B. Steroids ${ }^{2}$}

The commercially available steroids (hydrocortisone, cortisone, and 11-desoxycorticosterone) which had been donated to us were administered without chemical examination. The other alpha-ketolic cortical hormones, i.e., corticosterone (B), 11-dehydrocorticosterone (A) and 11-desoxy-17-hydroxycorticosterone $(S)$, were subjected to chromatography and found to be essentially pure as determined by this method. Steroids were administered as the acetate with the exception of corticosterone (B) which was given in the free form. The compounds were administered within the first hour of the metabolic day with the exception of cortisone acetate (in exp. No. 13) which was given in a dosage of $50 \mathrm{mg}$. every six hours for three and one-half days.

\section{Urine collection}

Urine was collected for 24-hour periods in brown glass bottles containing approximately $10 \mathrm{ml}$. of chloroform and kept in the ice box during and after the collection period. Creatinine was determined as a gross check on the accuracy of collections.

\section{Chemical Procedures}

\section{A. Hydrolysis and extraction}

Within a day after completing the collection of urine, the specimens were brought to $\mathrm{pH} 4.5$ with a mixture of sodium acetate and acetic acid so that the acetate concentration was 0.1 normal, and incubated for 48 hours at $38^{\circ}$ with 100 Fishman units per ml. of Viobin beef spleen $\beta$-glucuronidase using a few drops of $\mathrm{CHCl}_{3}$ as preservative. Glucuronidase incubated with distilled $\mathrm{H}_{2} \mathrm{O}$ under the same conditions gave no appreciable ultraviolet absorbing or blue tetrazolium reacting material.

The urines were then adjusted to $\mathrm{pH} 1$ and extracted for one hour with an equal volume of $\mathrm{CHCl}_{2}$ on an oscillating shaker, then washed with cold $0.1 \mathrm{~N}$ sodium hydroxide and water and evaporated to dryness in vacuo after drying over sodium sulfate.

Comment. Early in this study, the use of $\beta$-glucuronidase for hydrolyzing steroid conjugates was investigated. Neutral reducing lipid-soluble substances in urine were compared after hydrolysis at $\mathrm{pH} 1$ and after glu-

\footnotetext{
2 Steroids for administration to the experimental subjects and for use as standards were obtained through the generosity of the following individuals, institutions and companies :

Dr. Thomas F. Gallagher, Sloan-Kettering Institute for Cancer Research, Memorial Center, New York; Dr. Gregory Pincus, Worcester Foundation for Experimental Biology, Mass.; Dr. Hildegard Wilson, New York University, New York; Ciba Pharmaceutical Products, Inc., Dr. Ernst Oppenheimer and F. E. Houghton; Eli Lilly and Company, Dr. O. M. Helmer; Merck and Company, Drs. Elmer Alpert, Lewis H. Sarett, and Karl Pfister; Schering Corporation, Robert E. Waterman; G. D. Searle and Company, Dr. Irwin C. Winter; and The Upjohn Company, Dr. William J. Haines.
}

curonidase hydrolysis in a series of normal individuals and patients. In most cases, it was found that values approximating the plateau value were obtained by using the procedure outlined above. These values varied from 2 to 13 times the values obtained after extraction at $\mathrm{pH} 1$.

The effect upon the yield of alpha-ketolic steroids from aliquots of a large sample of urine was studied under the following conditions: 1) Extraction with chloroform at $\mathrm{pH} 1$ at room temperature for one hour; 2) extraction with chloroform after: (a) glucuronidase hydrolysis as indicated above, followed by (b) re-extraction with chloroform at $\mathrm{pH} 1$ for one hour; and 3) hydrolysis with glucuronidase as indicated above followed by hydrolysis at $\mathrm{pH} 1$ during a single extraction with chloroform for one hour. The yield of alpha-ketolic steroids with procedure No. 1 was $0.1 \mathrm{mg}$. per 24 hours; with procedure No. 2a, the yield was $1.1 \mathrm{mg}$. per 24 hours; with No. 2b there was a further yield of $0.3 \mathrm{mg}$. per 24 hours and with procedure No. 3 a yield of $1.4 \mathrm{mg}$. per 24 hours. Measurement of the reducing lipids gave similar results. As a result of these and other studies and considering the cost of the $\beta$-glucuronidase for the large volumes of urine hydrolyzed, procedure No. 3 was adopted as yielding most of the alpha-ketols present. More recent work has indicated that a $\mathrm{pH}$ of 4.8 is optimum for hydrolysis (5). It has also been demonstrated that hydrolysis is not complete at the plateau since addition of more glucuronidase and continued incubation, particularly after extraction of the corticoids released, gives still more steroid (6).

Re-extraction with an equal volume of $\mathrm{CHCl}_{3}$ indicated that about 85 per cent of the total of the two extractions was obtained on the first extraction. This was measured by determination of neutral reducing lipids and also by calculations from the areas of the alpha-ketol peaks on the paper chromatograms (see below).

\section{B. Paper chromatographic and micro-analytic technics}

The technic employed for paper chromatography was essentially that of Burton, Zaffaroni, and Keutmann (1). This was modified so that the strips could be read directly in a Beckman D.U. spectrophotometer by means of an adaptor (7). In addition, the volume of the effluent was the determining factor in development rather than time. Chromatograms were developed at "room temperature."

1. Separation. Strips of Whatman No. 1 filter paper, $1.3 \mathrm{~cm}$. wide, or multiples thereof, and $44.5 \mathrm{~cm}$. long, were saturated with propylene glycol and blotted between filter paper three times. A starting line was drawn $9 \mathrm{~cm}$. from one end, the other end being cut to a point. The extract was applied to the starting line in a spot not touching the edges. A micro-pipette was used and evaporation of the solvent was facilitated by a jet of dry nitrogen. The chromatograms were then developed essentially as described by Burton, Zaffaroni, and Keutmann (1). The strips were then removed and dried at room temperature. The first (most polar) fraction, $\mathrm{X}$, is found on the first strip after collection of 14 to $15 \mathrm{ml}$. of effluent per 1.3 $\mathrm{cm}$. width of strip. The running time varied from 72 to 96 hours. The effluent of the most polar fraction is 


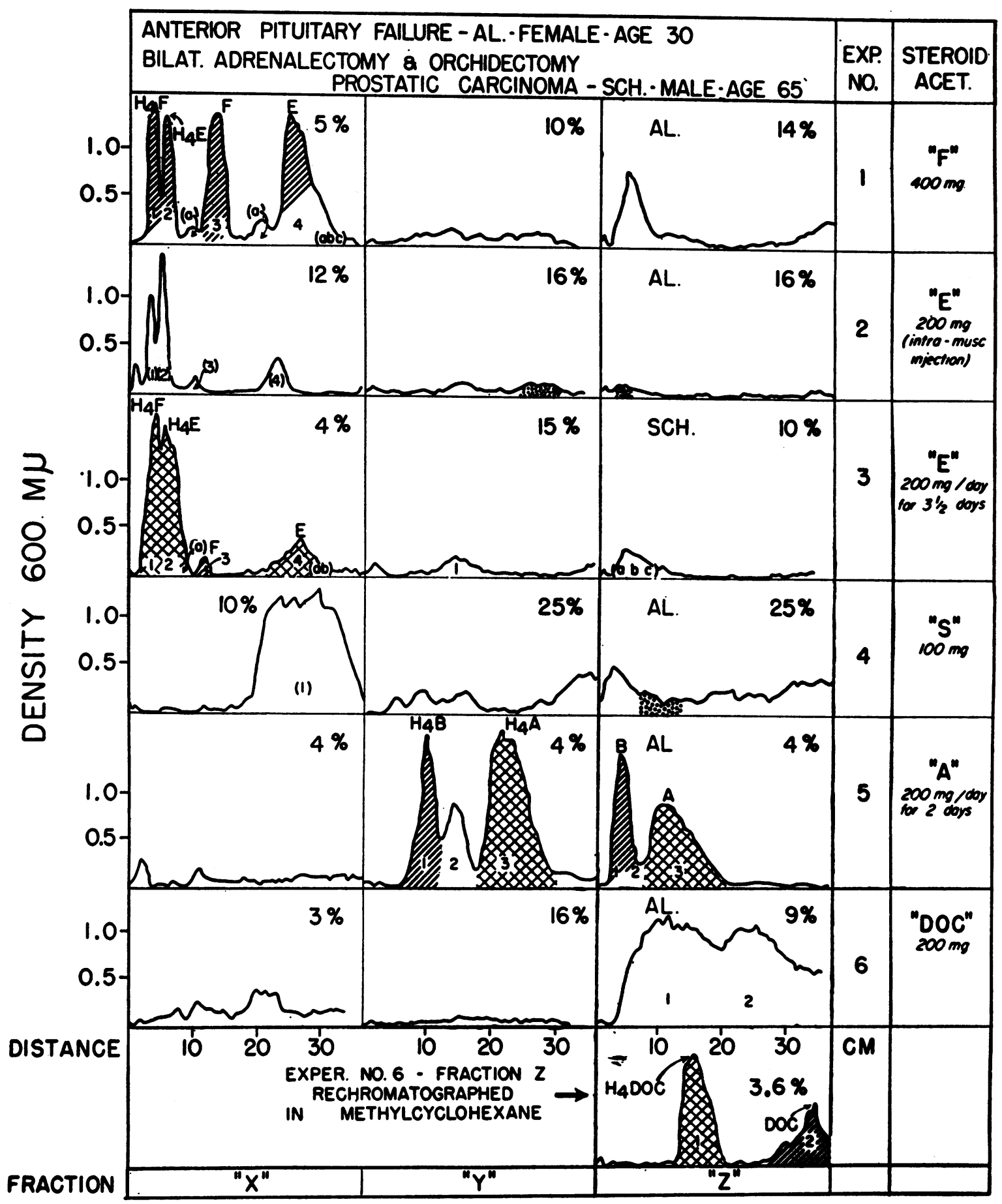

Figs. 1 and 2. Preliminary Chromatograms of Alpha-Ketolic Steroid Metabolites

Figures 1 and 2 illustrate the major alpha-ketolic chromatographic peaks found in the urine extracts following oral (or intramuscular-esp. No. 2) administration of various doses of active cortical hormones to subjects with markedly reduced or absent adrenocortical function. Experiments No. 7 and No. 8 (Figure 2) show the control studies.

The formulas given on Figure 2 are those of the free steroids. The corresponding acetates were administered in all cases except compound $B$. 


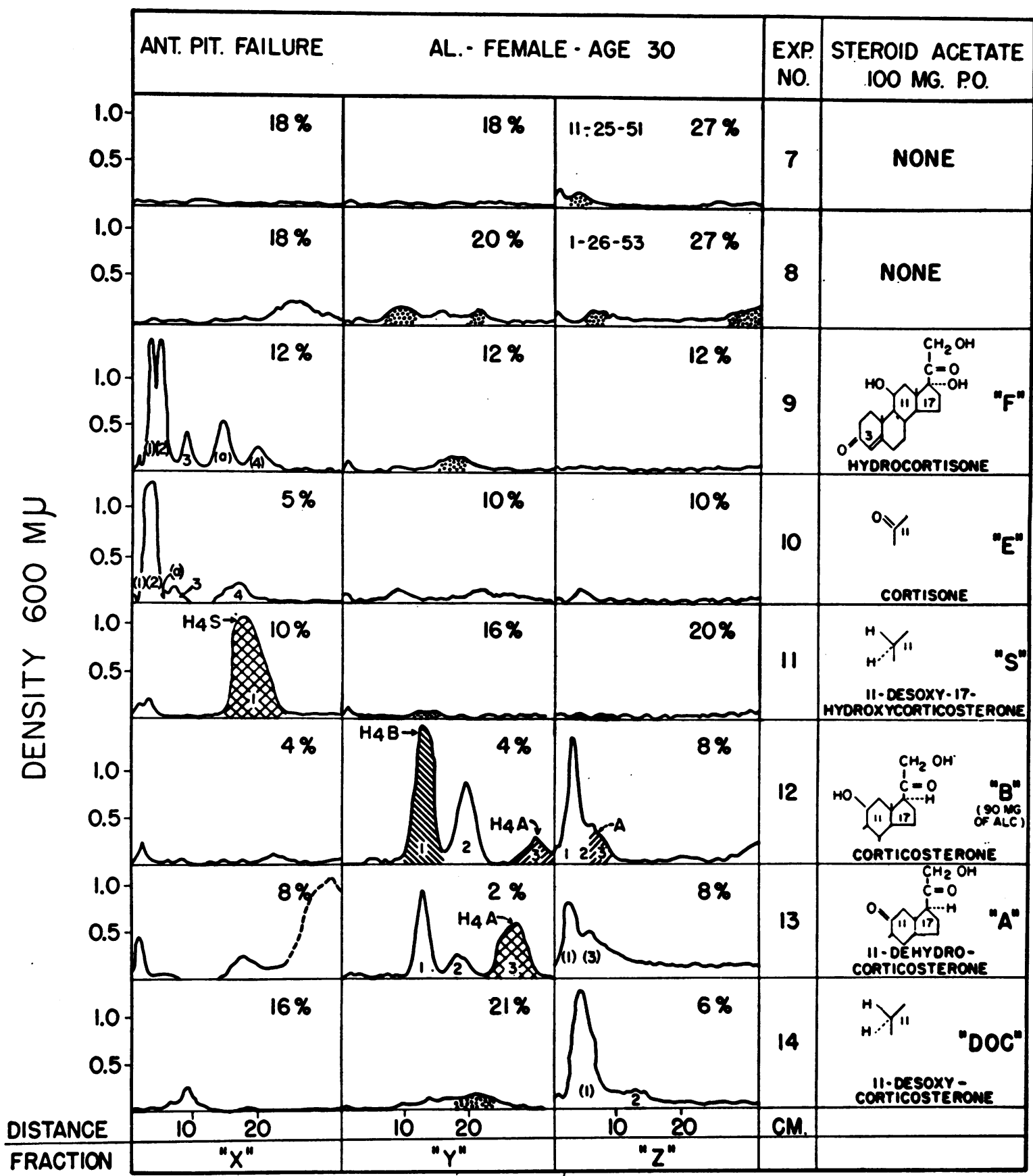

These "preliminary" chromatograms were developed in the toluene-propylene glycol system. After drying, they were sprayed with blue tetrazolium and the density of the blue color produced by reaction with the alpha-ketols was then determined in a Beckman D.U. spectrophotometer at $600 \mathrm{~m} \mu$. The density is charted as the ordinate in relation to the distance from the "starting line." The most polar (X), "mid-polar" (Y), and least polar (Z) fractions are charted. The percentage figures in each fraction indicate the proportion of the 24-hour urine extract used on the chromatogram. The dotted areas indicate zones of atypical color development. The dashed line for the last peak in the $X$ fraction, exp. No. 13, indicates that this peak is usually found in fraction $Y$, but the development of fraction $X$ was 


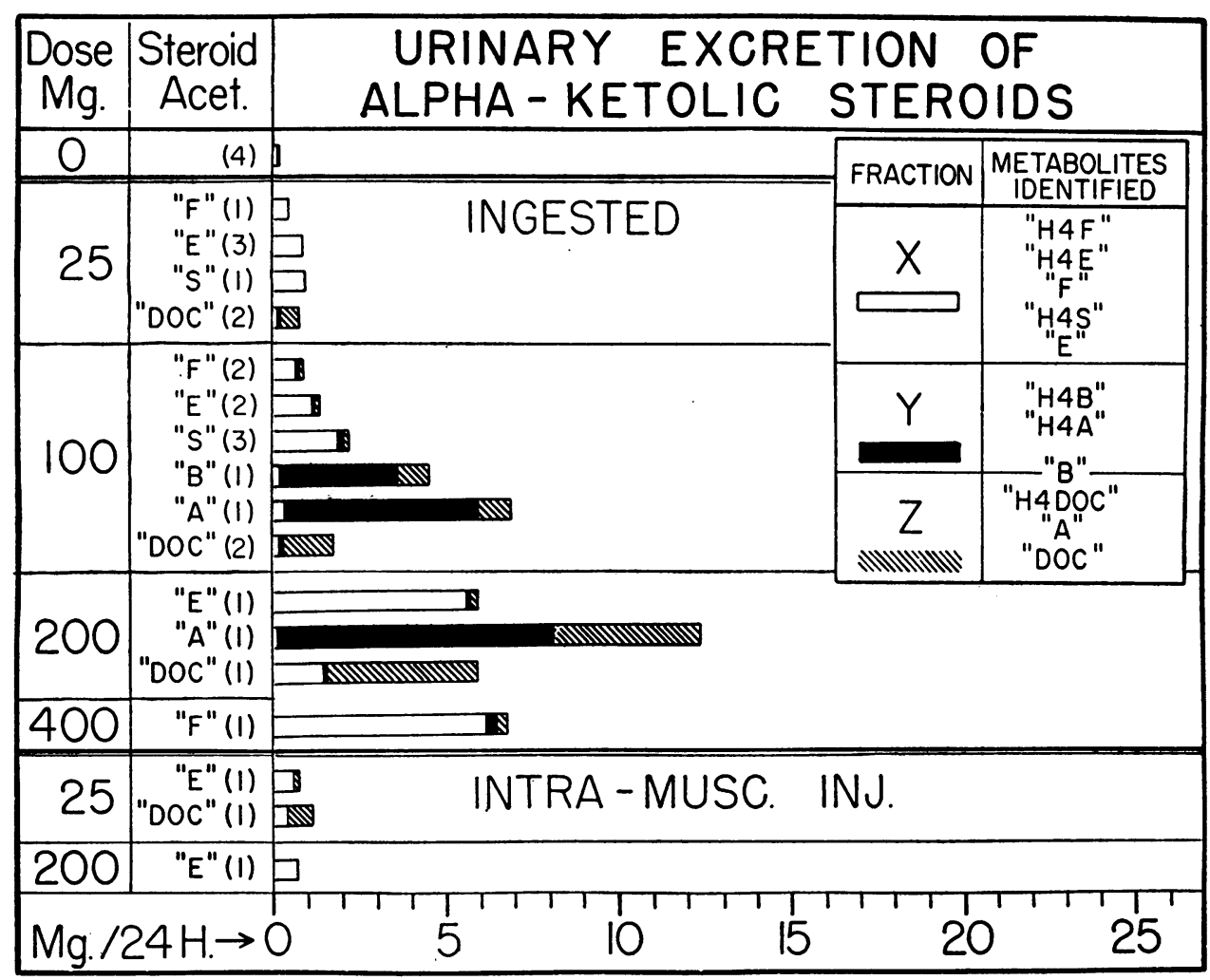

Fig. 3. Semiquantitative Estimation of Urinary Alpha-Ketolic Steroid Metabolite (AKSM) Excretion by Chromatographic Fractions

The decreasing polarity of the metabolites with decreasing polarity of the administered alphaketolic steroid is indicated by the marked increase in the $\mathrm{Y}$ and $\mathrm{Z}$ fractions after $\mathrm{B}, \mathrm{A}$, and DOC. The metabolites found after administration of F, E, S, B, A, and DOC are listed. (See Figures 2 and 3 and Tables $I$ and II for the specific metabolites found after administration of the individual steroids.)

evaporated to dryness and the residue applied as before to a second strip. Fraction $\mathrm{Y}$ appears on the second strip after collection of 3.5 to $4.0 \mathrm{ml}$. of effluent (15 to 24 hours). The effluent from strip $Y$ was evaporated to dryness and applied to a third strip which was developed only until the solvent front reached the end of the strip (3 to 6 hours). This third strip represents fraction $Z$.
The major alpha-ketolic steroids found in the various fractions are listed in Figure 3.

2. Detection of steroids. (a) Alpha-beta unsaturated ketones were determined by absorption of ultraviolet light at $245 \mathrm{~m} \mu$. (prior to spraying with blue tetrazolium). The absorption at $245 \mathrm{~m} \mu$. of the $1.3 \mathrm{~cm}$. wide paper strip was determined by means of the Beckman D.U. spectro-

not allowed to proceed to the standard amount of effluent in this instance. However, this peak was eluted and developed with fraction $Y$.

Identification: Since more than one alpha-ketolic steroid may be in the same position, further chromatography was a necessary prelude to identification studies (see Table I). Diagonally lined peaks indicate those metabolites isolated, purified and subjected to infrared spectrometric analysis $\| /$ or spectrometry in sulfuric acid /// or both $\$ 28 \%$. These peaks are considered as identified as indicated by the abbreviations (see Methods) above the peaks. Other numbered peaks, without parentheses were re-chromatographed with a standard and $R_{D o c}$ determined in one or more solvent systems as the free or acetylated forms and have been subjected to special tests as indicated in Table I. The peaks with numbers in parentheses have been numbered (without re-chromatographing) and $R_{\text {Doo }}$ calculated on the

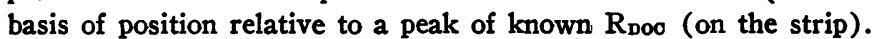

Peaks with the same number in similar fractions after administering the same compound are probably due to the same metabolite, although positive identification has been made only in those indicated by the diagonal lines. The same number after feeding of non-identical steroids does not indicate the two or more peaks so numbered to be identical in composition. Less completely studied peaks have been indicated by the letters $a, b$, etc. 
photometer fitted with an adaptor. Readings were taken at $7 \mathrm{~mm}$. intervals (or less if optical density changed) and the results plotted. The readings at $245 \mathrm{~m} \mu$. are not shown in the figures. (b) Alpha-ketolic compounds were then detected by the production of a blue color when the strip was sprayed with two parts of aqueous 0.2 per cent blue tetrazolium mixed with one part of 10 per cent sodium hydroxide solution. The absorption at $600 \mathrm{~m} \mu$. was determined, as described above, within one hour after air drying the strips following spraying with alkaline blue tetrazolium solution. The results were then plotted on the same graph so that a visual record was maintained of the "ultraviolet" and "blue tetrazolium" absorption curves (peaks) which demonstrated their relationship.

Comment. Although ultraviolet absorption at $245 \mathrm{~m} \mu$. is not specific for alpha-beta unsaturated ketonic steroids, nor is reaction with blue tetrazolium confined to alphaketolic steroids, these observations have proved a useful first step toward identification and provide a rough quantitative estimation as well as an exact location of blue tetrazolium peaks in relation to the ultraviolet peaks. In several series of quantitative chromatograms with the six cortical hormones, the ratios of the areas of the blue tetrazolium peaks, after spraying to the corresponding areas at $245 \mathrm{~m} \mu$, averaged about .7. Therefore a blue tetrazolium peak at the position of an ultraviolet peak having an area approximately 0.7 of that of the ultraviolet peak which does not change when chromatographed in other solvents or when chromatographed after acetylation suggests the presence of a compound having both the $\Delta^{\mathbf{4}}-3$-keto and alpha-ketol groups. The absence of ultraviolet absorption in a blue tetrazolium reacting zone suggests a "di- or tetrahydro" alpha-ketol. An ultraviolet peak with an area much greater than, or less than, the blue tetrazolium stained area implies the presence of a mixture. The shape of either curve may also indicate that more than one substance is present, but irregularities in distribution across the paper, visible to the eye, must be taken into consideration. The absence of peaks as determined by these technics does not necessarily mean that other types of steroids are not present, since steroids without the alpha-ketolic or $\Delta^{4}-3$-keto groups, as well as other substances, are not detected by these tests.

3. Re-chromatography. The chromatograms pictured in Figures 1 and 2 represent the "preliminary" chromatograms. For further characterization and identification, appropriate zones of unsprayed strips were selected on the basis of ultraviolet absorption and the position of blue zones on the parallel strip after spraying with blue tetrazolium solution. These zones were eluted with methanol and re-chromatographed in the appropriate system with the required standards as the free compound and after acetylation. Acetates usually required the methylcyclohexane-propylene glycol system. Acetylation and subsequent determination of $R_{D o o}$ afforded evidence concerning substituent groups. The use of such procedures often resulted in wide separation of two compounds with similar $R_{D o c}$ in the toluene-propylene glycol system.
It also frequently separated alpha-ketolic steroids from other ultraviolet absorbing material in the extracts. Some peaks, notably those in fraction $Z$, were best separated with methylcyclohexane as the mobile phase. In order to speed movement, the paper was saturated with 1:1 methanol-propylene glycol rather than pure propylene glycol. This procedure was used in the case of compounds $A$ and $B$ and their acetates with methylcyclohexane as the mobile phase. For separation of $\mathrm{H}_{4} \mathrm{~F}$ and $\mathrm{H}_{4} \mathrm{E}$ toluene was used as the mobile phase and the diluted propylene glycol as the stationary phase.

Comment. Reproducibility-Because of temperature variations, displacement effects and other factors, the $R_{\text {Doo may }}$ vary approximately 10 per cent; occasionally more. Absolute rates per unit time or per unit volume are also affected by variations in amount of propylene glycol and amount of extract on the paper.

4. Identification procedures. a. Determination of $R_{D o c}$. Relative mobility was expressed as distance moved on the strip with respect to DOC taken as unity as described by Burton, Zaffaroni, and Keutmann (1). Compounds of known $R_{D o c}$ were used where indicated. Distances were measured from the starting line to point of maximum absorption. $R_{D o c}$ was calculated from the following formula :

$$
\begin{array}{r}
\text { Unknown } R_{D O O}=\frac{\text { Distance moved by unknown }}{\text { Distance moved by standard }} \\
\times R_{D O 0} \text { of standard }
\end{array}
$$

For greatest accuracy, the substances should move an appreciable distance from the starting line but not too close to the lower end of the strip.

b. Reaction with blue tetrazolium. Described above.

c. Absorption of ultraviolet. Described above.

d. Reaction with phenylhydrazine. The Porter-Silber method (8) for determination of F and other 17-hydroxylated alpha-ketols was used. More recently, we have used a modified method (i.e., allowing the reaction mixture to stand overnight at room temperature). This gives identical extinction coefficients for all tested 17hydroxylated alpha-ketols.

e. Absorption spectra in sulfuric acid. The method of Zaffaroni (2) was employed, using micro-cells and approximately 8 to $10 \mu \mathrm{g}$. of the steroid. Special preparation of the paper strips and care with glassware was necessary for satisfactory results. All equipment must be washed with chromic acid and thoroughly rinsed with water and the elution solvent. All solvents are redistilled and tested for absorption characteristics. The paper strips used in final purification were washed in a beaker for three days in 3 per cent acetic acid, one day with water, and three days in methanol, with change of the solvents several times during each washing. After elution, the eluate was filtered through fritted glass to eliminate paper fibre. Using these precautions, satisfactory spectra can be obtained in most instances using pure sulfuric acid as a blank.

Comment. The absorption spectra in sulfuric acid appears to be a valuable tool in the identification of C-21 steroids. However, it is not always possible to differ- 
entiate stereo-isomers, nor in all cases can the saturated steroids be distinguished from those containing an isolated double bond $(2,9)$. In our experience, the absorption spectra for the alpha-ketolic steroids tested by us or reported by others $(2,9)$ are distinctive (except for some stereo-isomers) when extinction coefficients as well as maxima and minima are compared. Absorption curves for some standards and isolated compounds are shown in Figure 4.

f. Infrared spectrometry. Infrared spectrometry (10) was done if sufficient material was isolated. The analyses were made at the Sloan-Kettering Institute for Cancer Research, Memorial Center, New York City, through the courtesy of Dr. Thomas F. Gallagher. Steroids isolated by paper chromatography are frequently not sufficiently pure for infrared spectrometry. Therefore, they were purified further as their acetates on silica gel columns.

g. Miscellaneous procedures. 1) In general, the isolated substances which did not show ultraviolet absorption were subjected to the modified Pettenkofer reaction (11) using dehydroepiandrosterone as the reference standard. None of the isolated substances have shown a positive reaction in this test.

2) The quantitative anthrone test was applied to the substances isolated and suspected to be DOC (12).

3) The fluorescence of compounds $F$ and $B$ in sulfuric acid has been considered characteristic for these substances (13). A quantitative technic, modified by omission of the initial heating period, from that of Engel, Slaunwhite, Carter, and Nathanson (14) for estrogens was used, employing the primary and secondary filters for

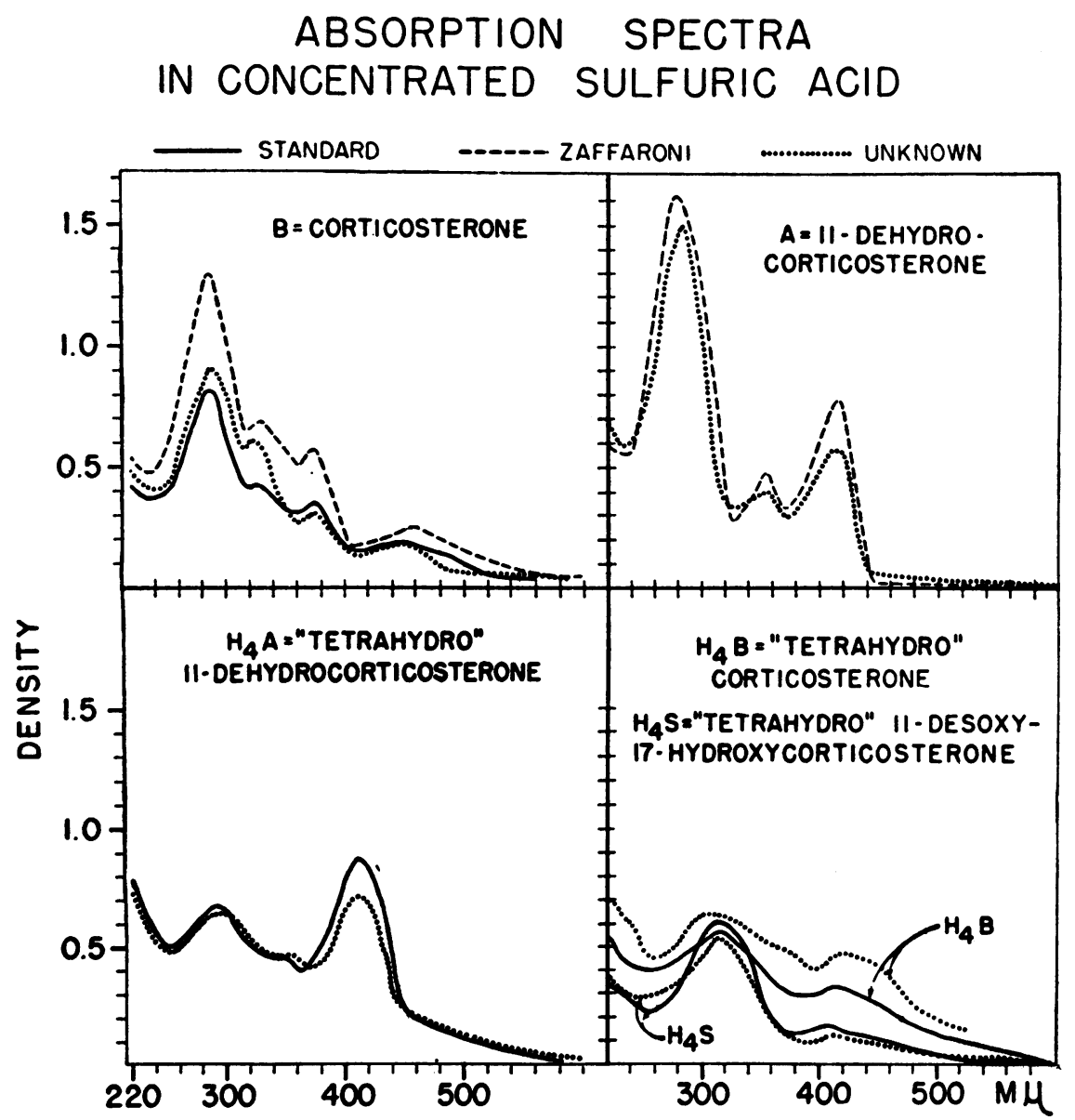

Fig. 4. Absorption Spectra in Sulfuric Acid

The experiment number and peak number indicating the source of the unknowns illustrated in this figure are as follows: $B-\exp$. No. 5 , peak $Z_{1} ; A-\exp$. No. 12, peak $Z_{3} ; H_{4} A-$ exp. No. 13 , peak $Y_{8} ; H_{4} B-\exp$. No. 5 , peak $Y_{1}$, and $H_{4} S-e x p$. No. 11 , peak $X_{1}$. Further identification data concerning these steroids are given in Table I and chromatograms are shown in Figures 1 and 2 . The similarity of $\mathrm{H}_{4} \mathrm{~B}$ and $\mathrm{H}_{4} \mathrm{~S}$ in regard to the region of maximum absorption and their dissimilarity in regard to relative density is illustrated. 
the $\mathrm{B}_{2}$ determination furnished with the Lumetron fluorimeter. It was found that none of the other active cortical hormones nor their normal $3-\alpha$ hydroxy derivatives show more than one-fifteenth the fluorescence of $F$. The fluorescence relative to hydrocortisone (F), taken as 100 per cent, of the neutral steroids tested is as follows : Corticosterone (B) 150 per cent; $\Delta^{4}$-pregnene-17 $\alpha, 20$, 21-triol-3-one 50 per cent; $\Delta^{4}$-pregnene-11 $\beta, 17 \alpha, 20,21$ tetrol-3-one 25 per cent; $\Delta^{4}$-androstene-17 $\alpha$-ol-3-one ("cis"-testosterone) 25 per cent; and $\Delta^{4}$-pregnene-17 $\beta$, 20, 21-triol-3-one 17 per cent. The following steroids gave less than 7 per cent: $\mathrm{H}_{2} \mathrm{~F}$ acetate; $\mathrm{H}_{4} \mathrm{~F}$ diacetate; $\mathrm{E} ; \mathrm{H}_{4} \mathrm{E}$ diacetate $; \mathrm{H}_{4} \mathrm{~B} ; \mathrm{A} ; \mathrm{H}_{4} \mathrm{~A} ; \mathrm{S} ; \mathrm{H}_{4} \mathrm{~S}$ acetate $; \mathrm{DOC}$; $H_{4}$ DOC; testosterone-17 $\beta$; progesterone; pregnane- $3 \alpha$, $20 \alpha$-diol ; and $\Delta^{5}$-pregnene-3 $\beta, 21$-diol-20-one.

h. Approximation of AKSM excretion. Studies with known compounds indicate that the area under the curves of density at $600 \mathrm{~m} \mu$. (as read directly from the paper) plotted against distance on the chromatogram appear to be directly related to the quantity of steroid between the values of 10 and 60 micrograms. The range of variation from the mean was \pm 30 per cent. An approximation of the amount in the extract of the 24-hour urine collection can be obtained from this estimate and the proportion of the 24-hour urine extract used on the chromatographic strip. This method can be used to indicate total AKSM as well as the estimation of a particular alpha-ketolic steroid metabolite.

\section{Group reactions}

The alpha-ketolic steroid metabolite (AKSF) excretion was approximated as described above. Lipid-soluble reducing substances (G'ase. R-L and Acid R-L) were determined, after both methods of hydrolysis, by the method of Heard, Sobel, and Venning (15). The total neutral 17 -ketosteroids were measured by a modification of the Holtorff-Koch technic (16) on aliquots extracted with carbon-tetrachloride without subjecting the material to Girard separation.

Comment. The lack of specificity of the reducing properties of lipid-soluble extracts is well recognized as is the non-ketonic and non-steroidal nature of some of the material measured as "total neutral 17-ketosteroids," i.e., not subjected to Girard separation. In addition, keto groups at positions other than carbon atom 17 contribute to the total.

\section{RESULTS}

Results are presented as follows: 1) control studies, 2) identification of alpha-ketolic steroid metabolites following the administration of known compounds, 3) semiquantitative estimates of identified alpha-ketolic steroid metabolites, 4) the chromatographic pattern of the major urinary alpha-ketolic steroids, and 5) the effects of administration of known alpha-ketolic steroids on group reactions. In the figures and tables, the re- sults are grouped in order of decreasing polarity according to the specific compound administered.

\section{Control studies}

The control chromatograms of the extracts of urine from subject AL. collected during periods when no steroids were administered are shown in Figure 2. These indicate the small amount of blue tetrazolium reacting material excreted during the control periods at the beginning and end of the experiments. Large amounts of the 24-hour extract were used on the chromatograms. The nature of the substance reacting with blue tetrazolium in the $\mathrm{X}$ fraction of the control study (exp. No. 8) is unknown. No urine was collected in the case of patient $\mathrm{SCH}$. in the absence of therapy. Since this man was adrenalectomized and orchidectomized, it is presumed that little alpha-ketolic steroid would be contributed by the subject. Control chromatograms in patient JO. (not shown) and three other patients with adrenal insufficiency have demonstrated the small amount of AKSM excreted in the urine of individuals with severe adrenal cortical insufficiency. Details concerning case histories are in the section on Methods.

\section{Identification of alpha-ketolic steroid metabo- lites}

Figures 1 and 2 show the preliminary chromatograms and Table I lists the results of the identification studies on the alpha-ketolic steroid metabolites (AKSM) extracted from the urine after administration of the six alpha-ketolic cortical hormones. Only those isolated materials subjected to infrared spectrometry or spectrometry in sulfuric acid (or both) in addition to the other studies are considered to be "identified." These studies indicate that the major alpha-ketolic metabolite of all six alpha-ketolic steroids is the socalled "tetrahydro" form. Infrared spectrometry indicated that the 3- $\alpha$ hydroxy pregnane configuration was present. (Suggestive evidence for the presence of allo- $\mathrm{H}_{4} B$ after feeding $B$ or $A$ will be considered in the discussion.) The "tetrahydro" derivatives of both $F$ and $E$ after feeding $E$ have been identified by infrared spectrometry as well as other tests. The isolation of tetrahydro derivatives of S, A, B, and DOC after feeding these compounds has also been confirmed by infrared spec- 
trometry. The standard samples of these compounds for use in our laboratory were obtained through the courtesy of the following: Pregnane$3 \alpha, 17 \alpha, 21$-triol-20-one, $\left(\mathrm{H}_{4} \mathrm{~S}\right)$, Dr. Thomas F. Gallagher (17); Pregnane-3 $\alpha$, 21-diol-20-one, $\left(\mathrm{H}_{4} \mathrm{DOC}\right)$, Dr. Thomas F. Gallagher (unpublished synthesis, Dr. A. L. Kemp); and from Dr. Karl Pfister, Merck \& Co., Pregnane-3 $\alpha, 11 \beta, 21-$ triol-20-one, $\left(\mathrm{H}_{4} \mathrm{~B}\right)$ (unpublished synthesis, Dr. David Taub), and Pregnane-3 $\alpha, 21$-diol-11, 20dione, $\left(\mathrm{H}_{4} \mathrm{~A}\right)$. The tetrahydro forms identified by various procedures including spectrometry in sulfuric acid but not infrared (due to lack of material) are as follows: tetrahydro $F$ after the administration of compound $F$, tetrahydro $A$ after feeding compound $B$, tetrahydro $B$ after feeding compound A, and allo tetrahydro B after feeding $B$.

The interconvertibility of the hydroxyl and keto substituents at carbon atom 11 of corticosterone (B) and 11-dehydrocorticosterone (A) as well as hydrocortisone $(F)$ and cortisone $(E)$ has been demonstrated by the isolation of $\mathrm{A}$ and $\mathrm{H}_{4} \mathrm{~A}$ after feeding $\mathrm{B} ; \mathrm{B}$ and $\mathrm{H}_{4} \mathrm{~B}$ after feeding $\mathrm{A}$; as well as $\mathrm{E}$ and $\mathrm{H}_{4} \mathrm{E}$ after feeding $\mathrm{F}$; and $\mathrm{F}$ and $\mathrm{H}_{4} \mathrm{~F}$ after feeding $\mathrm{E}$ (Figures 1 and 2 and Table I).

Comment: Others have previously demonstrated the interconvertibility in the human subject of these substituents for hydrocortisone (18), cortisone (19-21) and adrenosterone (22). As indicated above, all of the six administered alphaketolic steroids have been shown to be reduced in ring A. Reduction of the alpha-beta unsaturated ketone in ring $\mathrm{A}$ by the human subject has previously been demonstrated for many steroids, particularly those in the C-19 series such as testos- terone and the progesterone series (4) as well as for cortisone (19-21) and hydrocortisone (18). These findings have recently been summarized by Dorfman and Ungar (4). The reduction of ring A in DOC (23) and compound A (24) with concomitant reduction of the alpha-ketolic side chain has also been described. The tetrahydro forms of compounds S, B, A and DOC do not appear to have been described previously as urinary metabolites of their respective unsaturated parent compounds, nor has the formation of corticosterone from 11-dehydrocorticosterone and the reverse reaction been described previously.

\section{Estimation of identified alpha-ketolic steroid metabolites}

Table II lists the amounts of the identified alphaketolic metabolites that have been found in the urine after administration of the six compounds. The tetrahydro forms of the administered steroids F, E, B, and A are greater in amount than the tetrahydro forms of their conversion products, i.e., those resulting from interconversion of the hydroxyl and keto groups at carbon atom 11 .

Comment: The relatively high excretion of compound F (after $400 \mathrm{mg}$. as compared with that after $100 \mathrm{mg}$. of $\mathrm{Fac}$ ) in relationship to its metabolites suggests the possibility that the capacity of the metabolic systems responsible for the reduction of ring $\mathrm{A}$ and the interconversion at carbon atom 11 may have been overburdened. A similar pattern may be noted (by giving due consideration to the per cent of the 24-hour extract utilized) in Figures 1 and 2 by comparing those experiments in which 100 and $200 \mathrm{mg}$. of $A$ and 100 and 200

TABLE II

Semiquantitative estimation of identified urinary alpha-ketolic steroid metabolites (mg./24 hr.)*

\begin{tabular}{|c|c|c|c|c|c|c|c|c|c|c|c|c|c|}
\hline $\begin{array}{l}\text { Steroid } \\
\text { acetate } \\
\text { adm. }\end{array}$ & $\begin{array}{l}\text { Dose } \\
m g . / 24 \text { hr. }\end{array}$ & $\begin{array}{l}\text { Exp. } \\
\text { no. }\end{array}$ & $\mathbf{H}_{\mathbf{a}} \mathbf{F}$ & H.E & $\mathbf{F}$ & $\mathbf{E}$ & HAS & $\mathrm{H}_{4} \mathrm{~B}$ & $\mathbf{H}_{\mathbf{A}} \mathbf{A}$ & B & $\mathbf{A}$ & H.DOC & DOC \\
\hline $\begin{array}{l}\mathbf{F} \\
\mathbf{E} \\
\mathbf{S}\end{array}$ & $\begin{array}{l}400 \\
200 \\
100\end{array}$ & $\begin{array}{r}1 \\
3 \\
11\end{array}$ & $\begin{array}{l}0.9 \\
1.2 \\
-\end{array}$ & $\begin{array}{l}0.8 \\
3.4 \\
-\end{array}$ & $\begin{array}{l}1.5 \\
0.2 \\
-\end{array}$ & $\begin{array}{l}0.1 \\
0.6 \\
-\end{array}$ & $\overline{0}$ & $=$ & 二 & E & - & - & $\bar{z}$ \\
\hline $\begin{array}{c}\text { (As alc.) } \\
\text { A } \\
\text { DOC }\end{array}$ & $\begin{array}{r}90 \\
200 \\
200\end{array}$ & $\begin{array}{r}12 \\
5 \\
6\end{array}$ & - & E & E & Z & 二 & $\begin{array}{l}2.2 \\
2.0 \\
-\end{array}$ & $\begin{array}{l}0.5 \\
4.5 \\
-\end{array}$ & $\begin{array}{l}0.62 \dagger \\
1.0 \\
-\end{array}$ & $\begin{array}{l}0.1 \\
1.1 \\
-\end{array}$ & $\frac{\bar{z}}{2.7}$ & $\overline{-}$ \\
\hline
\end{tabular}

* Extractable by method used (hydrolysis with 100 units glucuronidase per ml. followed by extraction with $\mathrm{CHCl}_{8}$ at $\mathrm{pH}_{1}$ ). Identified by infra-red spectrometry and/or spectroscopy in sulfuric acid and other procedures listed in Table $\mathrm{I}$. $\uparrow$ Partial identification - see Table I. 
mg. of DOC were administered. The relative proportion of the material at the position of the parent compound is greater in those experiments in which $200 \mathrm{mg}$. was administered.

\section{The chromatographic pattern of the major urinary alpha-ketolic steroids}

Comparison of Figures 1 and 2 shows that there appears to be a similarity of pattern when the same steroid is administered although some differences are also present.

Comment: The decreasing polarity of the major alpha-ketolic metabolites with decreasing polarity of the administered steroid is obvious from inspection of Figures 1 and 2 as is the similarity of the pattern after administration of $F_{a c}$ and $E_{a c}$ and after $B$ and $A_{a c}$ administration. The characteristic patterns have been obtained in subject AL. (case No. 1) after doses of less than $100 \mathrm{mg}$. as well as in subject JO. (case No. 3) and other subjects (not shown).

\section{Group Reactions}

A. Semiquantitative estimation of total alphaketolic steroid metabolites ( $A K S M$ ): The AKSM excretion was calculated from the areas of the peaks in each fraction of the chromatograms and the proportion of the 24-hour urine extract chromatographed (see methods). Results by chromatographic fractions are charted in Figure 3 and the total AKSM are tabulated in relationship to other group reactions in Table III. Following administration of $25 \mathrm{mg}$. of the alpha-ketolic cortical hormone, urinary AKSM increased above base-line values but the administration of $200 \mathrm{mg}$. or more seems necessary to produce marked increases in excretion. The AKSM excretion following the administration of compound $F$ is less at comparable dose levels than for the other steroids administered. This corresponds to the finding of lesser amounts of G'ase $\mathrm{R}-\mathrm{L}$ in the urine in these experiments.

B. Neutral reducing lipids extractable after glucuronidase plus acid hydrolysis (G'ase $R-L$ ) and after acid hydrolysis alone (Acid $R-L$ ): Table III shows the urinary excretion of phosphomolybdic acid "reducing lipids" after the two methods of hydrolysis. The $25 \mathrm{mg}$. dose level had relatively little or no effect. In general, the acid
R-L is only slightly (but significantly) increased by the administration of $100 \mathrm{mg}$. or more of the alpha-ketolic steroids by mouth, but marked increases in the absolute amounts of G'ase R-L occurred.

Comment: As with the AKSM, the G'ase R-L excretion tended to increase with increasing doses of the administered steroid, although there was some variability. The values for Acid R-L and most of those for G'ase R-L (after the feeding of steroids) are within the limits found for normal individuals by the same methods (unpublished).

Thorn and his co-workers (25) have reviewed the effect upon group reactions of administration of adrenocortical hormones. Increased excretion of neutral reducing lipids following the administration of hydrocortisone and cortisone is a well recognized effect. Our finding of increased excretion of G'ase R-L after compounds S, B, A, and DOC should be expected, but apparently there is relatively little in the literature concerning it.

C. Ratio G'ase R-L to AKSM: The lowest ratio G'ase R-L to AKSM is found with the large doses of administered steroid, and the highest ratios are found in the control studies (Table III).

Comment: This is additional evidence that much of the material measured as R-L in urine after glucuronidase (and also after acid) hydrolysis is non-steroidal. However, some of the differences in the two values may well be explained by the fact that alpha-beta unsaturated ketones also reduce phosphomolybdic acid, although not to the same extent as the alpha-ketols.

D. Total neutral 17-ketosteroids: Table III shows the total neutral 17-ketosteroid excretion following the administration of the six alphaketolic adrenocortical hormones. There was considerable variability in the results. In general, amounts greater than the highest control values were excreted, although none of the values are greater than those found for normal young adults.

Comment: The finding of increased 17-ketosteroid excretion (by a "group reaction" technic) after the administration of those alpha-ketolic steroids with a hydroxyl function at carbon atom 17 (F, E, and S) is to be expected and agrees with other reports (25). The isolation and identification of 11-oxygenated 17-ketosteroids following the administration of cortisone $(19,25)$ and hy- 
TABLE III

Urinary excretion of metabolites measured by group reactions *

\begin{tabular}{|c|c|c|c|c|c|c|c|c|c|c|}
\hline \multirow{2}{*}{$\begin{array}{c}\text { Oral dose } \\
\text { (As acetate) } \\
\text { mg. }\end{array}$} & \multicolumn{2}{|c|}{$\underset{m s . / 24}{\operatorname{AKS}}$} & \multicolumn{2}{|c|}{$\begin{array}{l}\text { G'ase R-L† } \\
\text { mg./24 hr. }\end{array}$} & \multicolumn{2}{|c|}{ G'ase R-L/AKSM } & \multicolumn{2}{|c|}{$\begin{array}{l}\text { Acid R-Lt } \\
m g . / 24 ~ h r .\end{array}$} & \multicolumn{2}{|c|}{$\begin{array}{c}\text { 17-KSt } \\
\text { mg./24 hr. }\end{array}$} \\
\hline & Jo. & AL. & Jo. & AL. & Jo. & AL. & Jo. & AL. & JO. & AL. \\
\hline \multicolumn{11}{|c|}{ No medication } \\
\hline $\begin{array}{l}\mathbf{0} \\
\mathbf{0} \\
0 \\
0\end{array}$ & $\begin{array}{l}\overline{0.3} \\
0.1\end{array}$ & $\frac{<0.1}{0.1}$ & $\begin{array}{l}6.0 \\
6.0 \\
5.2\end{array}$ & $\begin{array}{l}3.2 \\
5.2 \\
9.4 \\
7.5\end{array}$ & $\begin{array}{l}-\overline{20} \\
52\end{array}$ & $\begin{array}{r}>32 \\
4\end{array}$ & $\begin{array}{l}2.6 \\
2.5 \\
2.3\end{array}$ & $\begin{array}{l}2.2 \\
2.1 \\
1.4 \\
1.9\end{array}$ & $\begin{array}{l}6.0 \\
3.5 \\
3.5\end{array}$ & $\begin{array}{l}2.0 \\
0.5 \\
3.1\end{array}$ \\
\hline \multicolumn{11}{|c|}{ Hydrocortisone (F) } \\
\hline $\begin{array}{r}25 \\
100 \\
400\end{array}$ & 0.7 & $\begin{array}{l}0.4 \\
0.9 \\
6.8\end{array}$ & 7.2 & $\begin{array}{r}4.5 \\
7.7 \\
13.3\end{array}$ & 10 & $\begin{array}{r}11 \\
9 \\
2\end{array}$ & 2.5 & $\begin{array}{l}1.7 \\
3.2 \\
5.4\end{array}$ & 8.9 & $\begin{array}{l}7.8 \\
3.5 \\
7.8\end{array}$ \\
\hline \multicolumn{11}{|c|}{ Cortisone $(E)$} \\
\hline $\begin{array}{l}25 \\
100 \\
200 \ddagger\end{array}$ & $\begin{array}{l}0.8 \\
1.2 \\
5.9 \ddagger\end{array}$ & $\begin{array}{l}0.7 \\
1.2\end{array}$ & $\begin{array}{l}8.7 \\
16.2 \\
20.9 \ddagger\end{array}$ & $\begin{array}{r}5.9 \\
16.3\end{array}$ & $\begin{array}{c}11 \\
14 \\
4 \ddagger\end{array}$ & $\begin{array}{r}8 \\
14\end{array}$ & $\begin{array}{l}2.0 \\
3.5 \\
2.8 \ddagger\end{array}$ & $\begin{array}{l}1.6 \\
2.8\end{array}$ & $\begin{array}{c}8.9 \\
6.6 \\
10.4 \ddagger\end{array}$ & $\begin{array}{l}5.3 \\
9.1\end{array}$ \\
\hline \multicolumn{11}{|c|}{ 11-Desoxy-17-hydroxy corticosterone (S) } \\
\hline $\begin{array}{r}25 \\
100\end{array}$ & 2.3 & $\begin{array}{l}0.9 \\
1.0 \\
3.0\end{array}$ & 23.3 & $\begin{array}{r}8.8 \\
10.0 \\
18.9\end{array}$ & 10 & $\begin{array}{r}10 \\
10 \\
6\end{array}$ & 2.7 & $\begin{array}{l}3.3 \\
2.2 \\
2.8\end{array}$ & 10.9 & $\begin{array}{l}3.8 \\
2.5 \\
7.6\end{array}$ \\
\hline \multicolumn{11}{|c|}{ Corticosterone $(B)$} \\
\hline $\begin{array}{c}90 \\
\text { (As alcohol) }\end{array}$ & & 4.2 & & 12.5 & & 3 & & 3.1 & & 2.5 \\
\hline \multicolumn{11}{|c|}{ 11-Dehydrocorticosterone $(A)$} \\
\hline $\begin{array}{l}100 \\
200\end{array}$ & & $\begin{array}{r}6.9 \\
12.2\end{array}$ & & $\begin{array}{l}25.4 \\
19.1\end{array}$ & & $\begin{array}{l}4 \\
2\end{array}$ & & $\begin{array}{l}3.9 \\
2.8\end{array}$ & & $\begin{array}{l}5.6 \\
6.7\end{array}$ \\
\hline \multicolumn{11}{|c|}{ 11-Desoxycorticosterone (DOC) } \\
\hline $\begin{array}{r}25 \\
100 \\
200\end{array}$ & $\begin{array}{l}0.9 \\
1.5\end{array}$ & $\begin{array}{l}0.4 \\
1.8 \\
5.6\end{array}$ & $\begin{array}{r}8.8 \\
15.2\end{array}$ & $\begin{array}{r}4.5 \\
15.1 \\
30.6\end{array}$ & $\begin{array}{l}10 \\
10\end{array}$ & $\begin{array}{r}11 \\
8 \\
5\end{array}$ & $\begin{array}{l}3.3 \\
2.7\end{array}$ & $\begin{array}{l}2.4 \\
2.2 \\
3.0\end{array}$ & $\begin{array}{l}6.9 \\
7.3\end{array}$ & $\begin{array}{l}1.8 \\
1.7 \\
5.3\end{array}$ \\
\hline \multicolumn{11}{|c|}{ Intramuscular injection } \\
\hline $\begin{array}{c}\text { Cortisone }(E) \\
25 \\
200\end{array}$ & 0.6 & 0.7 & 8.8 & 5.8 & 15 & 8 & 2.5 & 2.8 & 4.2 & 7.5 \\
\hline $\begin{array}{l}\text { 11-Desoxycort } \\
25\end{array}$ & erone & $O C)$ & 9.2 & & 8 & & 3.1 & & 9.1 & \\
\hline
\end{tabular}

* Italicized numbers indicate values greater than the highest control value for the subject. Subject JO. was a man, AL. a woman, both with severe adrenal cortical insufficiency.

$\nmid$ AKSM $^{-}$- Alpha-ketolic steroid metabolites.

G'ase R-L = Lipid-soluble reducing substance extractable after glucuronidase and acid hydrolysis.

Acid R-L $=$ R-L after acid hydrolysis only.

17-KS = Total neutral 17-ketosteroids.

† The $200 \mathrm{mg}$. dose of cortisone was administered to subject SCH., an orchidectomized, adrenalectomized man. 
drocortisone (18) establishes the fact that 11-oxygenated steroids with a keto group on carbon atom 17 may be formed from 17-hydroxylated alphaketolic steroids. In addition, etiocholane-3 $\alpha$-ol-17one has been identified following the administration of compound $S(26)$.

Thorn and his co-workers in their review (25) state that corticosterone, although increasing "17ketosteroids," is by no means as potent in this respect as $\mathrm{F}$ or $\mathrm{E}$. In our single experiment, there was no increase in "17-ketosteroids" when $90 \mathrm{mg}$. of $\mathrm{B}$ alcohol was administered. However, we have found that levels above those of the highest control values were present after administration of 100 and $200 \mathrm{mg}$. of $\mathrm{A}_{\mathrm{ac}}$ and $200 \mathrm{mg}$. of $\mathrm{DOC}_{\mathrm{ac}}$. The identification of neutral 17-ketosteroids following administration of alpha-ketolic steroids without a hydroxyl group at carbon atom 17 has not been reported (4). It seems probable that the increases noted with these alpha-ketols without a 17-hydroxyl group were primarily due to keto groups at other than the 17-position since the Zimmerman reaction is not specific for 17 -ketosteroids.

\section{DISCUSSION}

The terminology has been defined and the limitations of the methods discussed in the section on Methods. The exact meaning of the word "identification" as used in this paper has been defined in terms of the methods used (see Methods and Table I). Comments have been made after each section in Results. Therefore, only the more general implications will be discussed here.

The most prominent urinary alpha-ketolic metabolites of the physiologically active compounds (F, E, S, B, A, and DOC) administered to individuals with little or no adrenocortical function have been found to be the $3 \alpha$-hydroxy pregnane ("tetrahydro $\mathrm{H}_{4}$ ") derivatives of the individual parent compound. The finding of the $3 \alpha$-hydroxy normal configuration is in accord with previously reported work with compounds $F$ (18) and E (19, 21). It is considered likely that the so-called "dihydro" $\left(\mathrm{H}_{2}\right)$ forms may, at least in part, be intermediates in the reduction of ring $A$ to the tetrahydro form since Schneider (27) has identified "dihydro-E" $\left(\mathrm{H}_{2} \mathrm{E}\right)$ in normal male urine. In addition, Savard and Goldfaden (28) have recently demonstrated the production of $\mathrm{H}_{4} \mathrm{~F}$ from
$\mathrm{H}_{2} \mathrm{~F}$, and Ungar, Davis, Rosenkrantz, and Dorfman (29) $\mathrm{H}_{4} \mathrm{~S}$ from $\mathrm{H}_{2} \mathrm{~S}$. In addition, we have found small amounts of a substance that is probably $\mathrm{H}_{2} \mathrm{E}$ (see Table $\mathrm{I}$, exp. No. 3, peak $\mathrm{Y}_{1}$ ) after administration of $200 \mathrm{mg}$. of $E$ acetate per 24 hours to an adrenalectomized man.

These findings, in general, lend support to the tentative generalization of Dorfman and Ungar (4) that "the presence of the side chain at carbon17 directs the reduction of the double bond of the $\Delta^{4}$-3-ketone in ring A primarily to the 5- $\beta$ configuration whether or not an oxygen function is present at carbon-11." However, the recent work of Engel, Carter, and Springer (30) and findings of our own suggest that corticosterone (B) and possibly 11-dehydrocorticosterone (A) more readily form the allopregnane derivative than those alpha-ketolic steroids having a 17- $\alpha$-hydroxy group (E, F, and $S$ ). Engel and his co-workers have isolated and identified relatively large amounts of allopregnane-3 $\alpha, 11 \beta, 21$-triol-20-one (allo- $\mathrm{H}_{4} \mathrm{~B}$ ) from the urine of a man with rheumatoid arthritis given corticosterone. Our findings bearing on this problem are as follows: The $\mathrm{Y}_{2}$ peaks after administration of compound $A$ (exp. No. 5) and compound B (exp. No. 12) have similar characteristics as indicated in Table I. Similar characteristics including the absorption spectrum in sulfuric acid have been found for allopregnane-3 $\alpha, 11 \beta, 21$-triol-20-one (allo- $\left.\mathrm{H}_{4} \mathrm{~B}\right)$ isolated from the urine of a woman receiving ACTH (31), and identified by infrared spectrometry through the courtesy of Dr. Thomas F. Gallagher. An authentic sample synthesized by Dr. A. L. Kemp of the Sloan-Kettering Institute for Cancer Research, was used as the standard. It, therefore, seems probable to us that the $Y_{2}$ peaks in experiments No. 5 and No. 12 were in fact the $3 \alpha-$ hydroxy allo form of $\mathrm{H}_{4} \mathrm{~B}$. Less complete evidence suggests that the $Z_{2}$ peak in these two experiments is an isomer of $\mathrm{H}_{4} \mathrm{~A}$ probably the $3 \alpha$ hydroxy allo form. The $R_{D O O}$ of the free and acetylated peak $Z_{2}$ suggests that it may be a tetrahydro derivative of $A$ having either the allo $3 \alpha$ or the normal $3 \beta$ configuration. The similarity of the sulfuric acid absorption spectra to that of $\mathrm{H}_{4} \mathrm{~A}$ also indicates that this compound is a $\mathrm{H}_{4}$ derivative of compound A. Unfortunately, insufficient material was available for adequate infrared spec- 
trometry because of loss or alteration in the final purification procedures. Assuming these peaks to be in fact the $3 \alpha$-hydroxy allo derivatives, the ratio of the pregnane derivatives of compounds $A$ and $B$ (Table II) to their allo isomers varied from 1.5 to 5 .

In addition to the reduction in ring $\mathrm{A}$, we have found, as have others, that compounds $F$ (18) and $\mathrm{E}$ (19-21) are interconvertible and in addition have found compounds $B$ and $A$ to be interconvertible. The direct conversion products as well as their tetrahydro derivatives were found in the urine. It seems probable that interconversion of the hydroxyl and keto groups at carbon atom 11 may also occur after reduction of ring $A$ of compounds B and A, since Savard and Goldfaden (28) have recently demonstrated that the $11 \beta$ hydroxyl group is interchangeable with the 11keto function of tetrahydro $\mathrm{F}$ and dihydro $\mathrm{F}$.

\section{SUMMARY}

1. Hydrocortisone (F), cortisone (E), 17-hydroxy-11-desoxycorticosterone (S), corticosterone (B), 11-dehydrocorticosterone (A), and 11-desoxycorticosterone (DOC) have been administered to subjects with adrenal cortical insufficiency, and the major urinary alpha-ketolic steroid metabolites identified and semiquantitative estimations made of excretion. Identification procedures included $R_{D O C}$ in various solvent systems, special color reactions and infrared spectrometric analysis and spectrometry in sulfuric acid or both.

2. The tetrahydro $\left(\mathrm{H}_{4}\right)$ form ( $3 \alpha$-hydroxy pregnane configuration) of each was identified as a major alpha-ketolic metabolite. However, corticosterone (B) and 11-dehydrocorticosterone (A) each give lesser amounts of two additional alpha-ketolic metabolites saturated in ring $\mathrm{A}$ which appear to be the $3 \alpha$-hydroxy allopregnane derivatives of the parent compound and its C-11 interconversion product.

3. The interconversion of the keto and hydroxyl group at carbon atom 11 was demonstrated in the absence of a normally functioning adrenal cortex for corticosterone (B) and 11-dehydrocorticosterone (A) as well as for cortisone (E) and hydrocortisone $(F)$ by the identification of the appropriate conversion products and their "tetrahydro" derivatives.
4. The general similarity of the chromatographic pattern after administration of $F$ and $E$ as well as the similarity after $\mathrm{B}$ and $\mathrm{A}$ was demonstrated.

5. The urinary excretion of total alpha-ketolic steroid metabolites (AKSM), reducing lipids extracted after glucuronidase plus acid hydrolysis (G'ase. R-L), and those extractable after acid hydrolysis alone (Acid R-L), and the total 17ketosteroids (17-KS) was, in general, increased by the administration of these compounds. Considerable variability was experienced in these measurements.

\section{ACKNOWLEDGMENT}

We wish to acknowledge, with gratitude, the interest and support of Dr. C. C. Wolferth. We also wish to acknowledge the invaluable help of Dr. Thomas F. Gallagher through whose courtesy all infrared analyses were performed at the Sloan-Kettering Institute for Cancer Research, Memorial Center, New York.

\section{REFERENCES}

1. Burton, R. B., Zaffaroni, A., and Keutmann, E. H., Paper chromatography of steroids. II. Corticosteroids and related compounds. J. Biol. Chem., 1951, 188, 763.

2. Zaffaroni, A., Micromethods for the analysis of adrenocortical steroids. Recent Progress in Hormone Research, New York, Academic Press, 1953, vol. 8, p. 51.

3. Kinsella, R. A., Jr., Baggett, B., and Glick, J. H., Jr., Studies of enzymatically hydrolyzed urinary neutral lipids. Federation Proc., 1951, 10, 208.

4. Dorfman, R. I., and Ungar, F., Metabolism of Steroid Hormones. Minneapolis; Burgess Publishing Co., 1953.

5. Dustan, H. P., Mason, H. L., and Corcoran, A. C., Urinary formaldehydogenic corticoid as determined after enzymatic hydrolysis in normal subjects and in patients with adrenal and hypertensive disease. J. Clin. Invest., 1953, 32, 60.

6. Baggett, B., Kinsella, R. A., Jr., and Doisy, E. A., Hydrolysis of conjugates of urinary corticoids with $\beta$-glucuronidase. II. The isolation and determination of tetrahydrocortisone. J. Biol. Chem., 1953, 203, 1013.

7. Tennent, D. M., Whitla, J. B., and Florey, K., Two techniques in paper chromatography; application to ketosteroids. Anal. Chem., 1951, 23, 1748.

8. Porter, C. C., and Silber, R. H., A quantitative color reaction for cortisone and related 17, 21-dihydroxy20-ketosteroids. J. Biol. Chem., 1950, 185, 201.

9. Bernstein, S., and Lenhard, R. H., The absorption spectra of steroids in concentrated sulfuric acid. 
I. Method and data. J. Organic Chem., 1953, 18, 1146.

10. Dobriner, K., Katzenellenbogen, E. R., and Jones, R. N., Infrared Absorption Spectra of Steroids: An Atlas. New York, Interscience Publishing, 1953.

11. Munson, P. L., Jones, M. E., McCall, P. J., and Gallagher, T. F., A colorimetric method for estimation of dehydroisoandrosterone and its application to urine extracts. J. Biol. Chem., 1948, 176, 73.

12. Graff, M. M., McElroy, J. T., and Mooney, A. L., Chromogens produced by certain steroids with the anthrone reagent. J. Biol. Chem., 1952, 195, 351.

13. Reichstein, T., and Shoppee, C. W., The hormones of the adrenal cortex in Vitamins and Hormones, New York, Academic Press, 1943, vol. 1, p. 345.

14. Engel, L. L., Slaunwhite, W. R., Jr., Carter, P., and Nathanson, I. T., The separation of natural estrogens by counter-current distribution. J. Biol. Chem., 1950, 185, 255.

15. Heard, R. D. H., Sobel, H., and Venning, E. H., The neutral lipide-soluble reducing substances of urine as an index of adrenal cortical function. J. Biol. Chem., 1946, 165, 699.

16. Holtorff, A. F., and Koch, F. C., The colorimetric estimation of 17 -ketosteroids and their application to urine extracts. J. Biol. Chem., 1940, 135, 377.

17. Koechlin, B. A., Kritchevsky, T. H., and Gallagher, T. F., Partial synthesis of compounds related to adrenal cortical hormones. XV. 17- $\alpha, 21-$ dihydroxy- $\Delta^{4}$-pregnene-3, 20-dione (Reichstein's "Substance S"). J. Am. Chem. Soc., 1951, 73, 189.

18. Burstein, S., Savard, K., and Dorfman, R. I., The in vivo metabolism of hydrocortisone. Endocrinology, 1953, 53, 88.

19. Burstein, S., Savard, K., and Dorfman, R. I., The in vivo metabolism of cortisone. Endocrinology, 1953, 52, 448.

20. Burton, R. B., Keutmann, E. H., and Waterhouse, C., The conversion of cortisone acetate to other alphaketolic steroids. J. Clin. Endocrinol. \& Metab., 1953, 13, 48.

21. Lieberman, S., Katzenellenbogen, E. R., Schneider, R., Studer, P. E., and Dobriner, K., Isolation of uri- nary steroids after cortisone and adrenocorticotropic hormone. J. Biol. Chem., 1953, 205, 87.

22. Savard, K., Burstein, S., Rosenkrantz, H., and Dorfman, R. I., The metabolism of adrenosterone in vivo. J. Biol. Chem., 1953, 202, 717.

23. Horwitt, B. N., Dorfman, R. I., Shipley, R. A., and Fish, W. R., Metabolism of steroid hormones. IV. Conversion of desoxycorticosterone to pregnane diol-3 $(\alpha), 20(\alpha)$ in man and the chimpanzee. J. Biol. Chem., 1944, 155, 213.

24. Mason, H. L., Metabolites of 11-dehydrocorticosterone: Pregnane-3( $\alpha), 20$-diol-11-one. J. Biol. Chem., 1948, 172, 783.

25. Thorn, G. W., Jenkins, D., Laidlaw, J. C., Goetz, F. C., Dingman, J. F., Arons, W. L., Streeten, D. H. P., and McCracken, B. H., Pharmacological aspects of adrenocortical steroids and ACTH in man. New England J. Med., 1953, 248, p. 232, 284, $323,369,414,588$, and 632.

26. Birke, G., and Plantin, L.-O., On the metabolism of Reichstein's substance S. Science, 1953, 118, 751.

27. Schneider, J. J., Further isolation of adrenocortical compounds from male urine. J. Biol. Chem., 1952, 194, 337.

28. Savard, K., and Goldfaden, S. H., Metabolism of pregnane-11 $\beta, 17 \alpha, 21$-triol-3, 20-dione (dihydro compound F) and pregnane-3 $\alpha, 11 \beta, 17 \alpha, 21-$ tetrol-20-one (tetrahydro compound $F$ ) in human subjects. Federation Proc., 1954, 13, 288.

29. Ungar, F., Davis, J. W., Rosenkrantz, H., and Dorfman, R. I., The metabolism of pregnane-17 $\alpha, 21-$ diol-3, 20-dione, and pregnane-17 $\alpha, 21$-diol-3, 11, 20-trione in vivo. J. Biol. Chem., 1954, 207, 375.

30. Engel, L. L., Carter, P., and Springer, M. J., Isolation from urine of ketonic metabolites of administered corticosterone. Federation Proc., 1954, 13, 204 (and personal communications).

31. Touchstone, J. C., Bulaschenko, H., Richardson, E. M., and Dohan, F. C., The isolation of pregnane$3 \alpha, 11 \beta, 21$-triol-20-one; allopregnane-3 $\alpha, 11 \beta, 21$ triol-20-one; pregnane-3 $\alpha, 21$-diol-11, 20-dione, and $\Delta^{4}$-pregnene-11 $\beta, 21$-diol-3, 20-dione from the urine of normal subjects treated with corticotropin. Arch. Biochem. \& Biophysics, 1954, 52, 284. 